\title{
RECENT DEVELOPMENTS IN BIOMASS PELLETIZATION - A REVIEW
}

\author{
Wolfgang Stelte, ${ }^{\mathrm{a}} *$ Anand R. Sanadi, ${ }^{\mathrm{b}}$ Lei Shang, ${ }^{\mathrm{c}}$ Jens K. Holm, ${ }^{\mathrm{d}}$ Jesper Ahrenfeldt, ${ }^{\mathrm{c}}$ \\ and Ulrik B. Henriksen ${ }^{c}$
}

The depletion of fossil fuels and the need to reduce greenhouse gas emissions has resulted in a strong growth of biomass utilization for heat and power production. Attempts to overcome the poor handling properties of biomass, i.e. its low bulk density and inhomogeneous structure, have resulted in an increasing interest in biomass densification technologies, such as pelletization and briquetting. The global pellet market has developed quickly, and strong growth is expected for the coming years. Due to an increase in demand for biomass, the traditionally used wood residues from sawmills and pulp and paper industry are not sufficient to meet future needs. An extended raw material base consisting of a broad variety of fibrous residues from agriculture and food industries, as well as thermal pre-treatment processes, provides new challenges for the pellet industry. Pellet production has been an established process for several decades, but only in the past five years has there been significant progress made to understand the key factors affecting pelletizing processes. A good understanding about the pelletizing process, especially the processing parameters and their effect on pellet formation and bonding are important for process and product optimization. The present review provides a comprehensive overview of the latest insights into the biomass pelletization processes, such as the forces involved in the pelletizing processes, modeling, bonding, and adhesive mechanisms. Furthermore, thermal pretreatment of the biomass, i.e. torrefaction and other thermal treatment to enhance the fuel properties of biomass pellets are discussed.

Keywords: Biomass; Pelletization; Bonding; Torrefaction; Pre-treatment; Wood pellets

Contact information: a: Centre for Renewable Energy and Transport, Division for Energy and Climate, Danish Technological Institute, Gregersensvej, DK-2630 Taastrup, Denmark.; b: Biomass and Ecosystem Science, Faculty of Life Sciences, University of Copenhagen, 1958 Frederiksberg, Denmark; c: Department of Chemical and Biochemical Engineering, Technical University of Denmark, $2800 \mathrm{Kgs}$. Lyngby, Denmark; d: Chemical Engineering, DONG Energy Power A/S, 2820, Gentofte, Denmark;

*Corresponding author: stelte@gmail.com

\section{INTRODUCTION}

The depletion of fossil fuels (i.e. natural gas and oil) and the discussion about $\mathrm{CO}_{2}$-induced climate change (Berner 2003) have resulted in political decisions triggering the use of biomass for heat and power production in Europe and elsewhere (TolonBecerra et al. 2011). The utilization of biomass is an attractive option for power producers to reduce their $\mathrm{CO}_{2}$ emissions due to relatively easy implementation in existing infrastructures, especially when co-fired in coal-based power plants (Neville 2011). In contrast to wind and solar power that depend on weather and seasonal change, biomass 
can be stored and utilized when needed, thereby providing a continuous source for heat and power production (Dunnett and Shah 2007; Rosillo-Calle 2007; Schubert et al. 2009).

One of the major factors limiting the utilization of biomass for heat and power production is its low bulk density, resulting in inefficient and cost-intensive handling properties. The distances between biomass production sites, such as forest and agricultural land to industrial and residential areas, where the energy is needed, are often long and require significant logistics for transportation and storage (Rentizelas et al. 2009). The bulk density of biomass is about 40 to $150 \mathrm{~kg} / \mathrm{m}^{3}$ for grasses (Adapa et al. 2002; Larsson et al. 2008) and about 150 to $200 \mathrm{~kg} / \mathrm{m}^{3}$ for commercial woodchips (Robbins 1982). Pelletization of biomass increases the biomass bulk density to about 700 $\mathrm{kg} / \mathrm{m}^{3}$ (Sokhansanj and Turhollow 2004). Apart from density increase, pelletization offers several other benefits, such as a homogeneous shape and structure that is advantageous for automated feeding into boiler systems.

The pellet marked consists of global trade of biomass, and the European and North American pellet markets have been studied in great detail by Sikkema et al. (2011) (European Union) and Spelter and Toth (2009) (USA/Canada). Wood pellet production in the European Union was estimated to be about 10 million tons (Sikkema et al. 2011) and 6.2 million tons for North America (Spelter and Toth 2009) for the year 2009, which sums up to about 16.2 million tons total. Another study by Cocchi et al. (2011) estimated a slightly lower value for the global pellet production of about 14.3 million tons for the year 2010. The globally installed pellet production capacity for 2011 was estimated to be at about 30 million tons. All studies suggest a strong growth for both the European and North American pellet markets. The Finnish Pöyry Industry consulting company has predicted growth of the global pellet production capacity to 46 million tons by 2020 (Pöyry 2011). The market price for pellets is rather volatile and has been fluctuating between 112 and 142 Euro per ton within the years 2007 to 2011; the price seems to follow the price for crude oil and economic development. The price as of May 2012 was, according to the APX-ENDEX (2012), about 127 Euro per ton. Sikkema et al. (2011) have made a study of the European pellet market and conclude that the current pellet price is under pressure and that future demand of pellets is highly uncertain, while the European market is subsidy driven. High feed in tariffs and combined sulfur and carbon tax are named as major factors affecting the pellet market. The future development of the pellet market is seen to be highly dependent on the abolishment of existing and/or the establishment of new public support schemes and fossil fuel price development as well as new renewable energy obligations.

Increase in demand for pellets and the limited availability of wood resources has resulted in efforts to broaden the raw material base used for pellet production; fibrous residues from agriculture and food processing industry, such as straws, husks, and pulps are being considered. Co-firing of biomass in existing combined heat and power (CHP) plants is a relatively inexpensive and easy way to reduce the $\mathrm{CO}_{2}$ emissions of coal-fired power plants. There has been an increasing interest of power producers to obtain a "coallike" biofuel, such as pellets made from thermally pretreated (torrefied) biomass. Torrefied pellets have just been commercialized (van der Stelt et al. 2011).

Earlier pellet reviews (García-Maravera et al. 2011; Kaliyan and Morey 2009d; Tumuluru et al. 2011) have focused on different aspects of biomass pelletization. However, a lot of new developments have taken place in the pellet sector lately, e.g. the 
introduction of new raw materials and pre-treatment technologies, such as torrefaction. Furthermore, newer studies have focused on the fundamental understanding of the pelletizing processes, such as key process parameters, bonding mechanisms, and pretreatment technologies. Parts of the present review have also been published in a Ph.D. thesis at the Technical University of Denmark (Stelte 2011e).

\section{PELLETIZING PROCESS AND MODELLING}

The compaction of biomass into briquettes and pellets is an old process that has been known for more than 130 years. William H. Smith registered the first patent for biomass densification in 1880 (Smith 1880) in Chicago, Illinois. It describes a process where sawdust was heated up to $150^{\circ} \mathrm{C}$, put in a strong mold, and compressed using a steam hammer.

The different types of biomass densification are bailing, briquetting, extrusion, and pelletization (Tumuluru et al. 2010). With respect to the production of high density, solid energy carriers from biomass, briquetting, and pelletization are the two standard methods, and that is why the present review is limited to these two techniques. Both processes occur at high pressures and are two very closely related techniques. The basic processing difference is the use of a piston or screw press for briquetting, while biomass pellets are produced in a pellet mill. The size of the final products is different; pellets have a cylindrical shape and are about 6 to $25 \mathrm{~mm}$ in diameter and 3 to $50 \mathrm{~mm}$ in length (Alakangas 2010). There are European standards relevant for biomass pellets and raw material classification (EN 14961-1, EN 14961-2 and EN 14961-6), and corresponding international ISO standards are under development (ISO/CD 17225-1, ISO/CD 17225-2 and ISO/CD 17225-6). These standards set clear values for pellet dimensions, pellet quality, and composition (i.e. raw materials, ash content, and heavy metals) and are based on earlier-developed national standards that have been reviewed and compared in detail by García-Maraver et al. (2011).

Briquettes can have different shapes and are greater in their dimensions. The terms briquettes and pellets are often confused in the literature since they only recently have been defined more exactly with the introduction of international standards for solid biofuels. The specifications for biomass briquettes are defined accordingly in the European standard EN 14961-3 and the international standard ISO/CD 17225-3.

Biomass densification first became a commercial, large-scale process in the second half of the last century, and was used to increase the handling properties of biomass both for energy production and for animal feedstock. In North America, wood pellets came into existence in the 1970s with the primary purpose to resolve the energy crisis. They were mainly used by industrial, commercial, and institutional sectors for heating. Residential consumers followed in 1983 when the first pellet stoves were introduced to the market. The European markets started later, with Sweden running at the forefront beginning about 1980; afterwards, the market expanded all over Europe (PeksaBlanchard et al. 2007). This development was initially driven by an increase in prices for fossil fuels and good availability of residues from sawmills and the pulp and paper industry. Environmental regulations aiming to reduce carbon dioxide emissions and an increase in environmental consciousness of our society became important factors triggering the utilization of biomass for energy production (Bauen et al. 2009; Peksa- 
Blanchard et al. 2007). Political decision makers have set clear aims to reduce carbon dioxide emissions within the European Union within a short time, better known as the European 2020 goal. It targets to cut down the emission of greenhouse gases by $20 \%$ (based on emissions in 1990) and to have a share of $20 \%$ renewables in energy production by the year 2020 (Tolon-Becerra, 2011). The utilization of biomass is seen as one of the major contributors to reach this target in time and the reason for the strong growth of the European pellet market.

\section{Process Overview}

Pelletizing processes consist of multiple steps (Fig. 1), which include raw material pre-treatment, pelletization, and post-treatment. Pre-treatment steps depend a lot on the raw material characteristics, and generally consist of size reduction, drying, and conditioning. After pelletization, the pellets are transferred into a pellet cooler and screened to remove small particles.

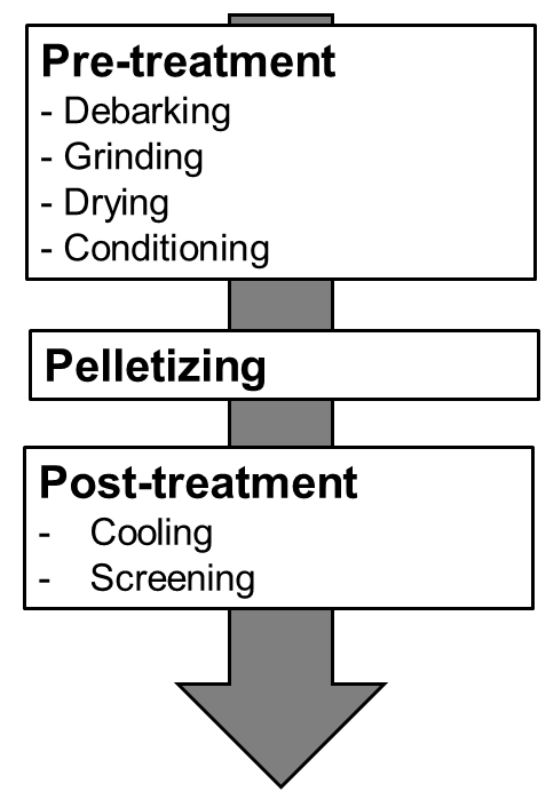

Fig. 1. A typical overview of the biomass densification process

Biomass feedstock for solid biofuels can be categorized into forestry, agriculture, and waste-based materials. These categories can be sub-divided into primary sources (directly produced materials) or secondary sources (derived from other processes) (Panoutsou 2011). Several studies have dealt with the optimization of biomass compaction processes. Some of the raw materials studied are listed in Table 1.

Wood is by far the most widely used raw material for pellet production today, while agricultural residues and grasses are more commonly used for briquetting processes. With respect to combustion properties (e.g. ash formation, slagging, and corrosion), wood has more favorable properties compared to agricultural residues and grasses. Nevertheless due to a limited availability of wood resources and a growing demand for pellets, alternative raw materials will gain further importance in the near future. In particular, industrial consumers are increasingly interested in firing agricultural biomass residues (Skøt 2011). 
Table 1. Biomass Resources in Densification Studies

\begin{tabular}{|l|l|}
\hline Biomass Resource & Reference \\
\hline Pine & $\begin{array}{l}\text { Arshadi et al. 2008; Filbakk et al. 2011; Finell et al. 2009; Holm et al. } \\
\text { 2007; Li and Liu 2000; Nielsen et al. 2009a; Nielsen et al. 2009b; } \\
\text { Nielsen et al. 2010; Samuelsson et al. 2009; Arrieche et al. 2011 }\end{array}$ \\
\hline Spruce & $\begin{array}{l}\text { Arshadi et al. 2008; Holm et al. 2011; Holm et al. 2007; Rhen et al. } \\
\text { 2005; Samuelsson et al. 2009; Stelte et al. 2011b; Stelte et al. 2011d }\end{array}$ \\
\hline Beech & $\begin{array}{l}\text { Holm et al. 2011; Holm et al. 2006; Holm et al. 2007; Stelte et al. 2011b; } \\
\text { Stelte et al. 2011d }\end{array}$ \\
\hline Eucalyptus & Pirraglia et al. 2012; Pirraglia et al. 2010 \\
\hline Poplar & Nielsen et al. 2010 \\
\hline Aspen & Nielsen et al. 2009b \\
\hline Oak & Li and Liu 2000; Nielsen et al. 2010 \\
\hline Salix & Biswas et al. 2011 \\
\hline Fir & Lam et al. 2011 \\
\hline Alfalfa & Adapa et al. 2002 \\
\hline Barley & $\begin{array}{l}\text { Faborode 1989; Mani et al. 2006; Odogherty and Wheeler 1984; } \\
\text { Serrano et al. 2011 }\end{array}$ \\
\hline Canola & Adapa et al. 2009 \\
\hline Oat & Adapa et al. 2009 \\
\hline Wheat & $\begin{array}{l}\text { Adapa et al. 2009; Mani et al. 2006; Odogherty and Wheeler 1984; } \\
\text { Smith et al. 1977; Stelte et al. 2011b; Stelte et al. 2011d; } \\
\text { Theerarattananoon et al. 2011 }\end{array}$ \\
\hline Rice & Chen et al. 2011; Faborode and Ocallaghan 1987 \\
\hline Rye & Narra et al. 2010 \\
\hline Reed canary grass & Larsson et al. 2008 \\
\hline Corn stover & $\begin{array}{l}\text { Kaliyan and Morey 2009a; Kaliyan and Morey 2009b; Kaliyan and } \\
\text { Morey 2009c; Kaliyan and Morey 2010b; Li and Liu 2000; Sokhansanj } \\
\text { and Turhollow 2004; Theerarattananoon et al. 2011 }\end{array}$ \\
\hline Corn cobs & Kaliyan and Morey 2010a \\
\hline Soy bean & Chen et al. 2011 \\
\hline Switch grass & $\begin{array}{l}\text { Gilbert et al. 2009; Kaliyan and Morey 2009a; Kaliyan and Morey 2009b; } \\
\text { Kaliyan et al. 2009c; Kaliyan and Morey 2010b }\end{array}$ \\
\hline Big blue stem & Theerarattananoon et al. 2011 \\
\hline Sugar cane bagasse & Erlich et al. 2005 \\
\hline Cotton & Coates 2000; Li and Liu 2000 \\
\hline Olive residues & Choi et al. 2009 \\
\hline Peanut hulls & Fasina 2008 \\
\hline Mixed residues & Gil et al. 2010 \\
\hline & \\
\hline
\end{tabular}

Pellets are produced in a mill that generally consist of a die with cylindrical press channels and rollers that force the biomass to flow into and through the channels. Due to the friction between the steel surface and the biomass in the press channel, a high back pressure is built-up and heat is generated. The physical forces that build up in the press channel of a pellet mill are crucial for understanding and optimizing the pelletizing process, and they have been the subject of multiple studies (Holm et al. 2006, 2007, 2011; Stelte et al. 2011b). A die with press channels and roller(s) are the basic parts of a pellet mill. The die can either be in the shape of a ring or a flat plate, as shown in Fig. 2. Either the die or the rollers can be rotating, and due to that movement, the biomass particles are squeezed into the openings of the press channel. 


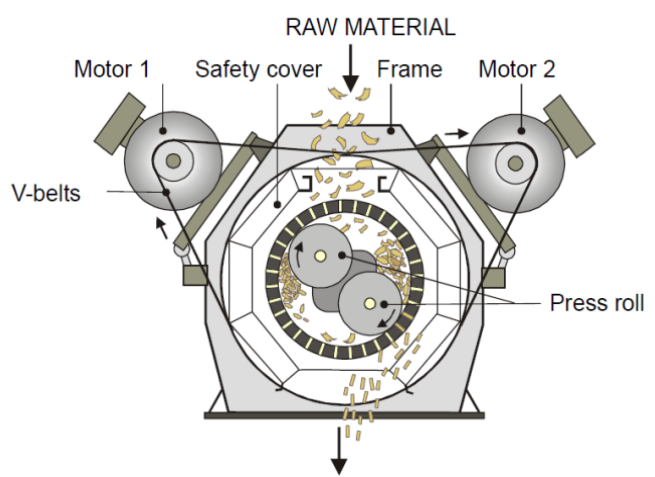

a)

Fig. 2. Typical pellet mill design a) ring die and b) flat die (Graphic adapted from Alakangas and Paju 2002).

The pelletization process takes place in the press channel of a pellet mill; this process has been the subject of several studies and modeling approaches (Holm et al. 2006, 2007, 2011; Larsson 2010; Nielsen et al. 2009b; Stelte et al. 2011b). During pelletization, biomass particles are fed into the mill. The basic design of a typical ring die pellet mill consists of a die with press channels and (usually two) eccentrically installed rollers. The rollers are located in close proximity to the die. The biomass in the mill is squeezed between roller and die and forced to flow into the press channels. Every time the roller passes the channel, the raw biomass is pressed into the channel, as illustrated in Fig. 3, and a layered structure of the pellet is produced.

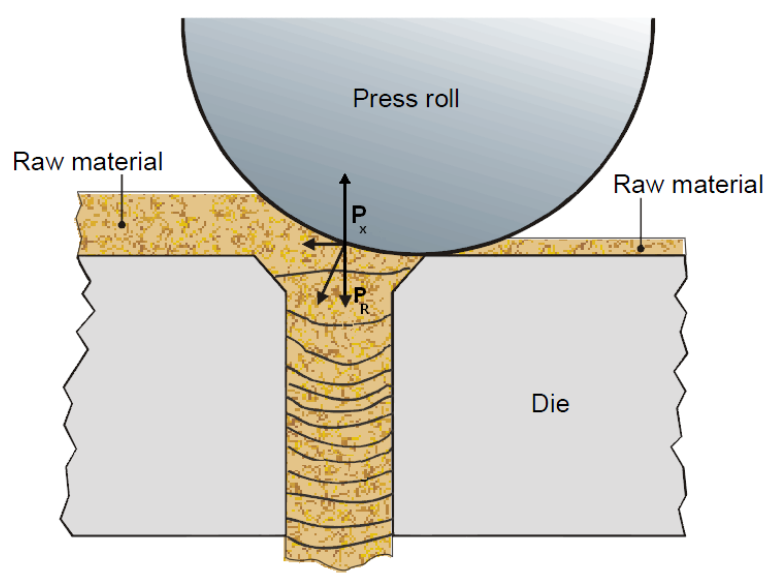

Fig. 3. Assembly of a pellet in the press channel of a pellet mill (Graphic modified based on Alakangas and Paju 2002)

Studies have shown that the aspect ratio ' $c$ ' (length/diameter) of the press channel is one of the most influential parameters determining the magnitude of the pressure $\left(P_{x}\right)$ 
generated in the press channel of a pellet mill (Faborode and Ocallaghan 1987; Faborode 1989; Holm et al. 2006, 2007; Stelte et al. 2011b).

The pressure exerted by the rollers of the pellet press $\left(P_{R}\right)$ is oppositely directed to the pressure built up in the press channel $\left(P_{x}\right)$ (Fig. 3). Under the assumption of steady state conditions both pressures $\left(P_{x}\right.$ and $\left.P_{R}\right)$ are in equilibrium. $P_{R}$ is limited within a certain range, as set by the size and motor power of the mill. When $P_{x}$ exceeds this range the press channels of the pellet mill will be blocked, since the rollers will not be able to provide the necessary pressure to push the materials through the channels. The optimal magnitude of $P_{x}$ is therefore a trade-off between the necessary pressure to produce stable pellets and the energy uptake by the pellet mill. High $P_{x}$ increases the risk of fires due to excessive heat development caused by friction, as well as energy uptake of the pellet mill.

\section{Forces and Modeling}

The mechanical forces acting on the biomass in the press channel of a pellet mill have recently been studied in great detail by Holm et al. (2011; 2006; 2007), and Nielsen et al. (2009a).

According to Holm et al. (2006), the major force acting on the biomass in the press channel is the friction force between the press channel wall and the biomass. Assuming that the biomass is an orthotropic material, where the fibers align perpendicular to the direction of the press channel, and that the biomass also is an elastic material, the pressure build-up in the press channel of a pellet mill $\left(P_{x}\right)$ can be described as a function of the friction coefficient $(\mu)$, the Poisson ratio $(v)$, press channel length $(L)$, and its radius $(R)$. The fibers are elastically deformed when exposed to a radial pressure, and this pressure gives rise to a longitudinal elongation of the fibers (Poisson effect). Since the channel walls are fixed, it is converted into a transverse pressure on the channel walls, resulting in friction. The friction gives rise to back pressure that is under steady-state conditions in equilibrium with the oppositely directed pressure exerted by the rollers and has been expressed by Holm et al. (2006), as described in Equation 1.

$$
P_{x}=\frac{P_{N 0}}{v_{L R}}\left(e^{2 \mu v_{L R} x / r}-1\right)
$$

This model was later verified by experiments using a single pellet press (Holm et al. 2007) and further optimized (Holm et al. 2011) so that it can be used to facilitate fast testing of pelletization behavior of new types of biomass. The latest study also addresses the dependency of the forces observed in the press channel on the temperature. All together, these studies present a method that allows pellet producers to estimate the pelletizing behavior of new types of raw materials by conducting a few tests in a single pellet press unit. The data from these tests in combination with the presented model can be used to estimate key process parameters for a production-size pellet mill, i.e. optimal press channel length and moisture content. This can reduce both time and costs for process development and optimization. The schematic diagram in Fig. 4 shows how a few tests in a single pellet press at low aspect ratios suffice to predict the force in a production size pellet mill. It has to be noted that high aspect ratios obtained in production scale pellet presses are difficult to study in single pellet presses due to the extremely high pressures that set a physical limit to what can be achieved in a single pellet press unit. 
This also explains the gap between single pellet press and industrial scale pellet press data points in Fig. 4.

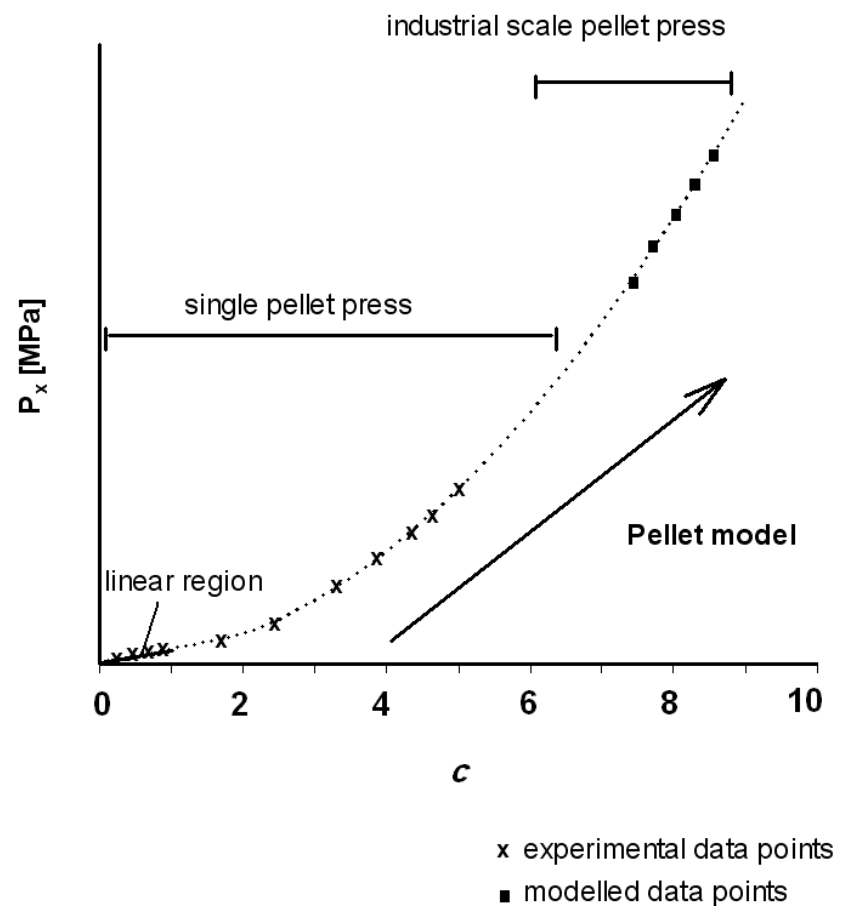

Fig. 4. Schematic diagram showing how testing with a single pellet press (SPP) unit in combination with modeling can predict the performance of an industrial pellet mill. $P_{x}$ is the pressure build-up in the press channel and $c$ is the aspect ratio (length/diameter) of the pellet. Single pellet press trials were done as aspect ratios between 0.1 and 5 , and the model was used to estimate pressures that will likely occur in production size pellet mills with higher aspect ratios of about 8 to 10. Graphic reprinted with permission from Holm et al. 2011 (c) American Chemical Society.

Nielsen et al. (2009a) studied the pelletizing process in great detail and subdivided it into three different components that sum up to the overall energy consumption of the process. These components were compression, flow, and friction, as shown in Fig. 5. Every time the roller approaches the surface of the die, the biomass is compressed and forms a temporary layer on the die surface (compression component). The flow component represents the energy required to force the compressed layer into the press channels, and the friction component stands for the energy required to press the compressed biomass in the channels. The work required for the three components can be determined experimentally for different raw materials and process parameters. The resulting data provide an estimate for the energy consumption of the pelletizing process that can be used for process design and optimization.

Other studies (Adapa et al. 2002; Mani et al. 2004) have focused on the compaction behavior of different biomass types by conducting a pelletizing test in a single pellet unit and fitting the obtained data to different mathematical models found in the literature. The models having the best fit to the experimental data were identified and used to explain the compaction mechanism of biomass. 


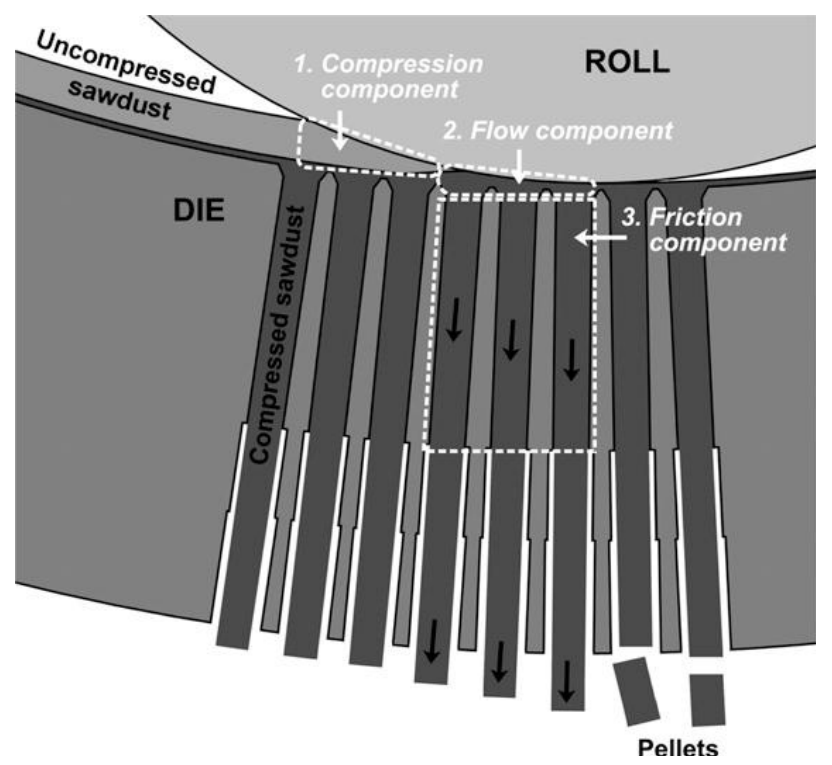

Fig. 5. Illustration of the pelletizing process (Nielsen et al. 2009a). A section of a press channel row is used to illustrate the die/roll/sawdust system. The components of the pelletizing process are allocated to the positions marked by the white dashed lines (see text). The lower part of the press channels with larger diameter is not part of the pelletizing. Graphic reprinted with permission from Nielsen et al. 2009a (C) Society of Wood Science and Technology.

\section{Process Energy Consumption}

The energy requirement for the pelletization of biomass has been the subject of different studies (Nielsen et al. 2009a; Odogherty and Wheeler 1984; Reed and Bryant 1979). Reed and Bryant (1979) studied the energy required for commercial pelletizing processes. They showed that both production rate and electrical energy used are strongly correlated to the raw material type and processing conditions, such as feed size and moisture content. The tested materials included saw dust, aspen wood, Douglas fir, and municipal solid waste. The fraction of product energy consumed during pelletization was about 1 to $3.1 \%$, while the average electrical energy required to pelletize biomass was roughly between 16 and $49 \mathrm{kWh} / \mathrm{t}$. Odogherty and Wheeler (1984) studied the energy required to press wafers out of wheat straw and found a linear relationship between the pellet density and specific energy required for pressing. Nielsen et al. (2009a) studied the contribution of the different components of a pelletizing process (Fig. 5) to the total energy consumption and determined the work required for the flow, compression, and friction contributions for the pelletization of beech and pine at various temperatures and moisture contents. They concluded from their studies that a large fraction of the process energy is used to make the biomass flow into the inlets of the press channels, what they defined as the "flow component".

\section{Key Process Parameters}

Several studies have been made to identify the key process parameters of biomass densification, affecting both process and product: 


\section{Moisture content}

The effect of raw material moisture content on the pelletizing properties and product quality has been the subject of several studies (Andreiko and Grochowicz 2007; Arshadi et al. 2008; Carone et al. 2011; Filbakk et al. 2011; Kaliyan and Morey 2009b; Mani et al. 2006; Nielsen et al. 2009b, 2010; Odogherty and Wheeler 1984; Rhen et al. 2005; Ryu et al. 2008; Serrano et al. 2011; Smith et al. 1977; Stelte et al. 2011b). In these studies, biomass was pelletized at different levels of moisture content, and its impact on the pellet quality (durability or compression stability) was analyzed. In general, the optimum moisture content for wood species was found to be between 5 to $10 \%$ (wt.), while it was slightly higher for agricultural grasses (between 10 to $20 \%$ (wt.)).

The optimum moisture content for the densification of beech was 6 to $10 \%$ (wt.) (Nielsen et al. 2009a; Stelte et al. 2011b), for spruce it was about 10\% (wt.) (Stelte et al. 2011b), for olive pulp it was 5\% (wt.) (Carone et al. 2011), and for pine it was about 6 to 8\% (wt.) moisture content (Nielsen et al. 2009a). The optimum moisture contents for the pelletization of grasses are significantly higher. For unspecified straw, in general, the optimum moisture content was found to be between 10 to $15 \%$ (wt.) (Odogherty and Wheeler 1984), for barley it was straw 19 to $23 \%$ (wt) (Serrano et al. 2011), for wheat straw it was about $15 \%$ (wt) (Smith et al. 1977; Stelte et al. 2011b), and for corn stover it was about $10 \%$ (wt) (Kaliyan and Morey 2009b). Increase in moisture contents above the optimum have been shown to have a negative influence on the pellet's mechanical properties (Carone et al. 2011; Kaliyan and Morey 2009d; Nielsen et al. 2009a; Serrano et al. 2011; Stelte et al. 2011b) and to reduce the pellet's density (Kaliyan and Morey 2009d; Odogherty and Wheeler 1984).

Apart from the quality of the densified product, the densification process itself is influenced by the moisture content. Andrejko and Grochwitz (2007) concluded from their studies that the energy consumption to compact ground lupine seeds into pellets was dependent on moisture content. They found that the energy input necessary to compact the ground seeds to a constant volume decreased with an increase in moisture content within the range of 9.5 to $15.0 \%$ (wt.). Nielsen et al. (2009a) have shown that an increase in moisture content for pine and beech results in a decrease of the energy requirement for different components of the pelletizing process. The influence of moisture content on the behavior the amorphous polymers in the biomass and the properties of the pellets (Stelte 2011c) will be discussed later.

\section{Temperature}

The effect of temperature on biomass densification has been studied to a significant extent (Filbakk et al. 2011; Gilbert et al. 2009; Kaliyan and Morey 2009b; Nielsen et al. 2009a; Rhen et al. 2005; Serrano et al. 2011; Stelte et al. 2011b). Heat is generated during pelletization due to the friction between biomass and the press channels of the mill. Serrano et al. (2011) studied the heat distribution by taking thermographic images of a pellet press, and found that the temperature of a die under operation at stable conditions is about $90^{\circ} \mathrm{C}$, while the temperature of a pellet leaving the press channel is just at about $70^{\circ} \mathrm{C}$ and cooling rapidly once it has left the press channel (Fig. 6). This difference could be due to a limited heat transfer from the die to the pellet due to a short retention time of the biomass in the press channel and/or a poor heat transfer between the metal surface and the biomass. 
The first studies of the temperature effects on biomass densification were conducted by Smith et al. (1977) where they investigated the dependency of straw briquette density on the applied temperature within a range of 60 to $140^{\circ} \mathrm{C}$. Their study showed that the density increased as the temperature increased until it reached $90^{\circ} \mathrm{C}$, while any further temperature increase did not result in higher densification. They also observed that the stability of pellets were enhanced and suggested that thin layers of waxes around the stem (cuticula) melt and solidify during this process. The waxes can serve as an adhesive between individual straw fibers. Other studies suggest the opposite, that is a negative effect of plant waxes (such as in wheat straw) on interparticle bonding due to the formation of a weak boundary layer (Bikerman 1967; Stelte et al. 2011d, 2012a).

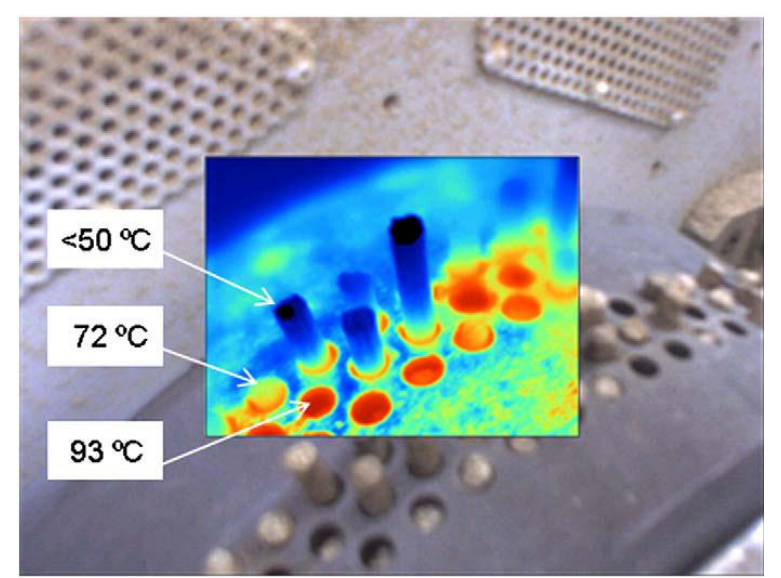

Fig. 6. Thermographic image of a pellet press die. Graphic reprinted with permission from Serrano et al. 2011 (c) Elsevier.

A recent study conducted by Stelte et al. (2011c) has shown that wheat straw waxes undergo a glass transition at 40 to $50^{\circ} \mathrm{C}$ (below the temperature where density improvements were observed), while wheat straw lignins showed a strong glass transition at 65 to $75^{\circ} \mathrm{C}$ ( $8 \%$ moisture content), which is much closer to the observed improvements. Indeed, several studies (Gilbert et al. 2009; Kaliyan and Morey 2010b; Stelte et al. 2011d) have suggested that lignin glass transition and subsequent flow and hardening result in improved wetting and enhanced contact area, followed by the inter-penetration of polymer chains from adjacent particles. This leads to higher mechanical properties of a pellet.

The increase in mechanical properties of the pellets with an increase in temperature was reported for spruce (Rhen et al. 2005), corn stover (Kaliyan and Morey 2009b), switch grass (Gilbert et al. 2009), pine (Nielsen et al. 2009a), olive (Carone et al. 2011), beech (Nielsen et al. 2009a), and wheat straw (Stelte et al. 2012a). Furthermore, it was reported that an increase in temperature reduces the friction in the press channel of the mill (Stelte et al. 2011b) (Fig. 7) and lowers the energy requirement for different components of the pelletizing process (Nielsen et al. 2009a).

Considering the effect of die temperature on the pelletizing process, it has been investigated that the friction decreases with an increase in die temperature. Stelte et al. (2011b) have measured the backpressure built up in the press channel during the 
pelletization of different biomass resources (beech, spruce, and wheat straw) and found a decrease with an increase in temperature. They suggested that wood extractives migrating to the pellet surface at elevated temperatures and polymer softening lower the friction in the press channel. In case of wood, it has been shown by means of infrared spectroscopy of the pellet surface that spruce contains lipophilic extractives, most likely tall oils, which lowers the friction in the press channel. Tall oil (also known as pine oil or rosin oil) is a mixture of fatty acids, resin acids, and sterols. It can migrate to the pellet surface at elevated temperatures. Such substances are substantially absent at ambient temperature or in case of pellets made from wood species containing little amounts of tall oil, such as beech (Stelte et al. 2011b). The migration of tall oil to the pellet surface is enhanced at higher temperatures. Its lubricating properties are likely the reason for the sharp drop of $P_{x}$ at about $70^{\circ} \mathrm{C}$ (Fig 7).

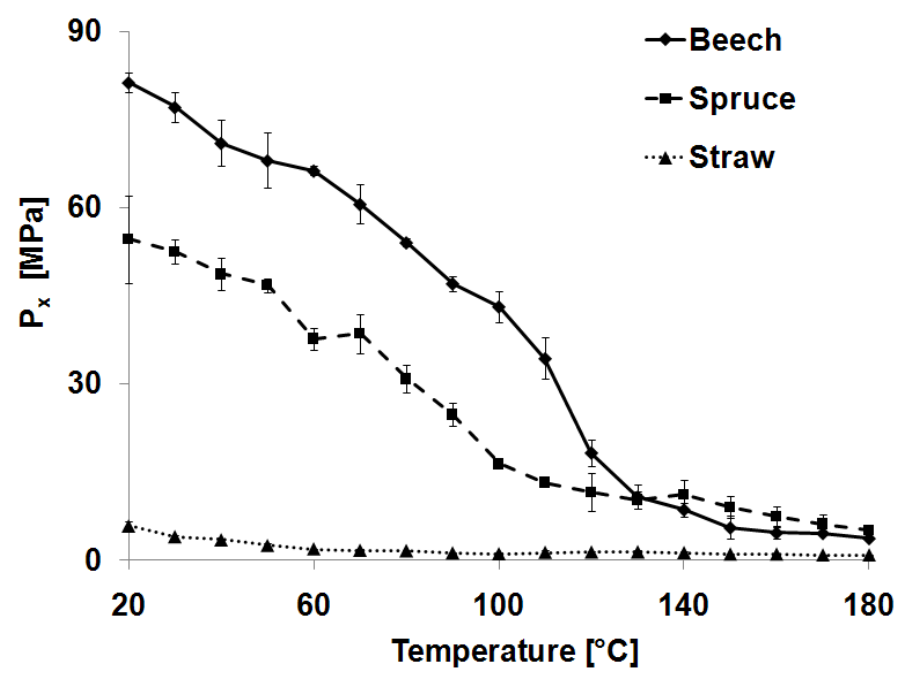

Fig. 7. Pressure build-up in the press channel of a pellet press $\left(P_{x}\right)$ related to temperature. The shown data is based on the pelletization of beech, spruce and straw ( $8 \%$ wt. moisture content) in a single pellet press test unit. Graphic reprinted with permission from Stelte et al. 2011b (c) Elsevier.

\section{Particle size}

Different studies have been conducted on the impact of particle size on the compaction properties of biomass (Filbakk et al. 2011; Jensen et al. 2011; Kaliyan and Morey 2009b; Mani et al. 2006; Serrano et al. 2011; Stelte et al. 2011b). Stelte et al. (2011b) have shown that the friction in the press channel of a pellet mill increases with decreasing particle size for beech particles due to an increase in surface area contact between the particles and the channel wall. Regarding pellet quality, Kaliyan and Morey (2009b) have found out that decreasing particle size for corn stover grinds results in an increased briquette density. Similar results were observed by Mani et al. (2006), who found that particle size significantly affects the density for pellets made from barley straw, corn stover, and switch grass, but not in the case of wheat straw. A study made by Serrano et al. (2011) indicated opposite results, suggesting smaller particles resulted in less dense pellets. Their difference compared to other studies was explained by the use of an industrial pellet mill instead of laboratory scale single pellet press units. 
The optimum particle size depends on the densification process, and briquetting processes can in general tolerate larger particles then pelletizing processes, for pellet production particles are usually below $5 \mathrm{~mm}$ in diameter. And in general, a broad variation of particle size is best with respect to pellet quality. However an amount of fines (particles smaller than $0.5 \mathrm{~mm}$ in diameter) that is too high in the raw material has a negative impact both on friction and pellet quality. As a rule of thumb, the amount of fines should not exceed 10 to $20 \%$ unless a binding agent is added.

Jensen et al. (2011) described a method that can be used to investigate the particle size distribution within a biomass pellet, which is different from the raw material (before pelletization), since particle size decreases during pelletization. They suggest that wet disintegration combined with mechanical impact is the most suitable method to determine the internal particle size distribution of a biomass pellet.

\section{Press channel dimensions}

The diameter of a press channel varies according to the desired product diameter, usually between 6 to $25 \mathrm{~mm}$ for a biomass pellet (Alakangas 2010). The press channel length and the ratio between length and diameter, also known as the compression ratio $(c)$ or aspect ratio, is the most important factor influencing the pressure built up in the press channel of a pellet press (Holm et al. 2006). It has therefore been subject to multiple studies (Faborode and Ocallaghan 1987; Faborode 1989; Holm et al. 2006, 2007, 2011; Odogherty and Wheeler 1984; Stelte et al. 2011b; Čolović et al. 2010). Faborode and O'Callaghan (1987) were the first to study the relationship between the aspect ratio and the compaction pressure. They tested the impact of the aspect ratio on the pressure that is built-up in the press channel during pelletization. Their data clearly shows an exponential correlation between the aspect ratio and the built-up pelletizing pressure. The physical forces acting on a pellet in the press channel of a mill were further studied by Holm et al. (2006; 2007; 2011). Their studies resulted in a pellet model that can be used to estimate the pressure build up in a pellet mill (Fig. 4).

Colović et al. (2010) studied the impact of the press channel length on the physical quality of cattle feed pellets, and they concluded that an increase in press channel length resulted in higher mechanical properties of the pellets (e.g., harder pellets).

For wood pellet production, the aspect ratio is usually around 6, while it can be up to 11 to 12 in the case of pellet production from wheat straw. The optimum length depends to great extent on the chosen raw material and processing conditions (i.e. temperature, moisture content, particle size).

\section{Pelletizing pressure}

The pressure the biomass is exposed to during pelletizing and briquetting has a significant impact on the product density and durability, as well as on the process energy consumption. This process parameter has therefore been subject of various studies (Adapa et al. 2009; Butler and McColly 1959; Carone et al. 2011; Gilbert et al. 2009; Kaliyan and Morey 2009b; Mani et al. 2006; Odogherty and Wheeler 1984; Smith et al. 1977; Stelte et al. 2011b). Studies have been conducted for straws, wheat (Adapa et al. 2009; Gilbert et al. 2009; Mani et al. 2006; Smith et al. 1977), barley (Adapa et al. 2009; Mani et al. 2006; Odogherty and Wheeler 1984), canola (Adapa et al. 2009), alfalfa (Butler and McColly 1959), and oat (Adapa et al. 2009). Other biomass residues tested 
where corn stover (Kaliyan and Morey 2009b; Mani et al. 2006), switchgrass (Gilbert et al. 2009; Kaliyan and Morey 2009b; Mani et al. 2006), olive residues (Carone et al. 2011), and wood (Stelte et al. 2011b). The product density of biomass compacted at different pressures has been studied extensively (Adapa et al. 2009; Faborode and Ocallaghan 1987; Gilbert et al. 2009; Kaliyan and Morey 2009b; Mani et al. 2006; Odogherty and Wheeler 1984; Smith et al. 1977; Stelte et al. 2011b). Furthermore, the mechanical properties (Carone et al. 2011; Gilbert et al. 2009; Kaliyan and Morey 2009b) and energy content (Odogherty and Wheeler 1984) were measured and compared for samples pressed at different pressures. In all the studies, there is a very clear agreement that concludes that pellet and briquette density increases with an increase in pressure. The correlation between pressure and density follows a saturation curve with the plant cell wall density as an upper limit.

Maximum applied pressures ranged from $50 \mathrm{MPa}$ (Odogherty and Wheeler 1984) to $600 \mathrm{MPa}$ (Stelte et al. 2011b); the pressure typically used in most studies was above 50 MPa (Adapa et al. 2009; Mani et al. 2006; Stelte et al. 2011b). The mechanical properties, compressive strength (Gilbert et al. 2009), and durability (Carone et al. 2011; Kaliyan and Morey 2009a) improved with an increase in pressure and follow a saturation curve, as already observed for the pellet density (Stelte et al. 2011b). Building up the pressure in either a pellet mill or briquetting press requires energy. From previous studies, it can be concluded that there is a certain threshold of pressure and that above this pressure, additional energy put into the process is mainly converted into excess heat, rather than contributing to better pellet quality.

\section{BONDING MECHANISMS}

The understanding of the bonding mechanisms between biomass particles within a fuel pellet or briquette is crucial for the production of high quality fuels. The bonding mechanisms have been the subject of only a few studies so far (Kaliyan and Morey 2010b; Lam et al. 2011; Stelte et al. 2011d). Nevertheless, a lot of knowledge can be transferred from related fields, such as pharmaceutical tableting (Hiestand 1997; Leuenberger and Rohera 1986), powder and agglomeration technology (Pietsch 2002), fiber board manufacturing (Bouajila et al. 2006), wood-thermoplastic panel boards (Sanadi and Caulfield, 2008), wood welding (Delmotte et al. 2008; Delmotte et al. 2009; Mansouri et al. 2010; Pizzi et al. 2006), and materials science in general.

One area of science that has been studied intensively during the last century is the production of pharmaceutical tablets. Tablet pressing of powder materials is a wellknown process that has been studied intensively and has been the subject of extensive reviews (Hiestand 1997; Leuenberger and Rohera 1986). In general, there are two important aspects to consider when pelletizing granular materials and these are: 1) the behavior of the particle under pressure, and 2) the interactions between the particles (Steward 1950). The pressure at a constant compression rate increases with time during densification processes as shown in the compression curve in Fig. 8 (Pietsch 2002).

According to Rumpf (1962) and Pietsch (2002), bonding forces between particles in compacted bodies can be classified into: 1) solid bridges, 2) attraction forces between solid particles, 3) mechanical interlocking, 4) adhesion and cohesion, and 5) interfacial forces and capillary pressure. These bonding mechanisms have been identified and 
assumed also to be valid for densified forage and wood residues (Mohsenin and Zaske 1976; Tabil 1996).

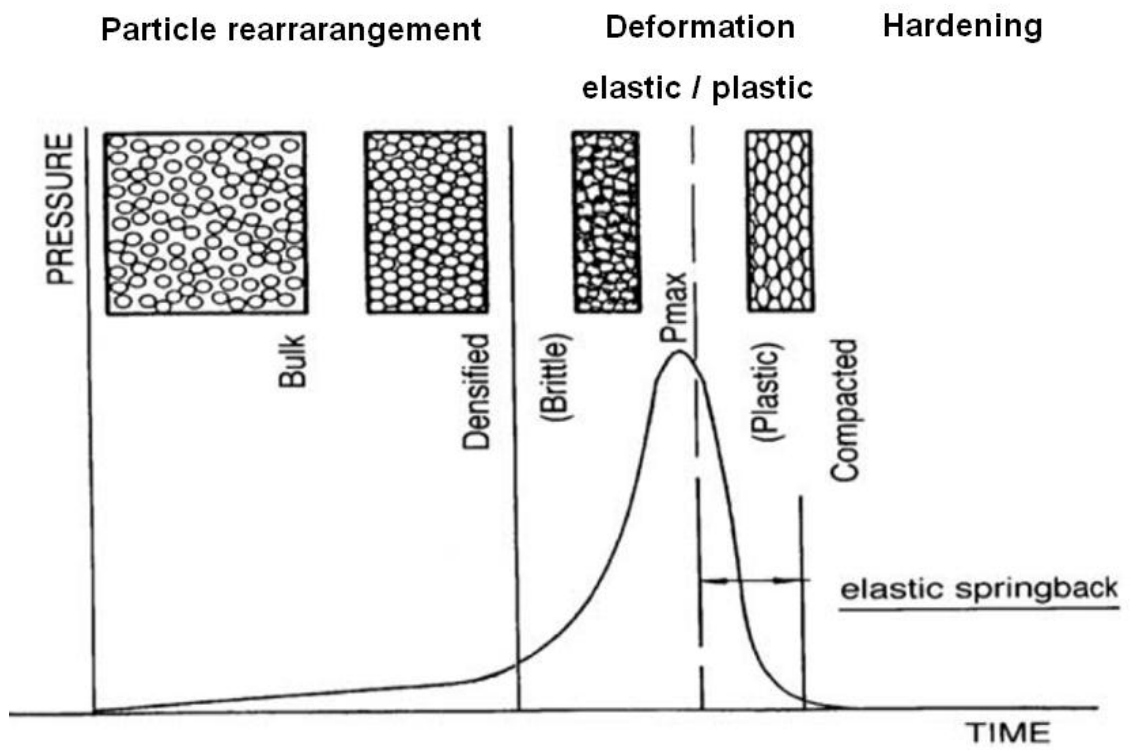

Fig. 8. Powder compression curve (Graphic modified from Pietsch 2002). The densification process can be separated into different stages, i.e. particle rearrangement, elastic and plastic deformation and hardening.

Mani et al. (2004) have analyzed compression curves of various grasses and interpreted them. The densification process can be separated into different stages, as shown in Fig. 8. Initially, the pressure builds up slowly because particles rearrange in a way that they fill less space, and air located in the pores between the particles is removed when pressing. With further compression of the materials, particles are in very close proximity to each other and short range bonding forces, i.e. van der Waals forces and electrostatic forces make them adhere to one another. After a certain point, no further packing can be obtained, and particles are pressed against each other, undergoing elastic and plastic deformation and fiber interlocking (Pietsch 2002). In case of plant cells that contain a large inner volume (vacuole) filled with air (dried biomass), the cell structure breaks up and the vacuole is compressed. At the same time, cell wall compounds (i.e. lignin and hemicelluloses) are expected to be released from the cell and to interact with surrounding particles (Odogherty 1989). Due to the high temperature and pressure, lignin softens and flows, resulting in improved wetting along with molecular inter-diffusion and entanglement of polymer chains between adjacent fibers. This phenomenon has earlier been described as "solid bridge" formation (Kaliyan and Morey 2010b) and is important for the pellet strength (Stelte et al. 2011d). The density increases with pressure until it reaches a maximum which, in the case of plant biomass, can be expected to be close to the density of the plant cell wall (Stelte et al. 2011b).

Bond formation between wood particles has been intensively addressed in wood science and wood technology, and knowledge can be transferred to pelletizing processes. Wood welding, like pelletization and briquetting, is a process where heat and pressure is applied to biomass, resulting in bond formation. The mechanism behind friction welding of wood has been studied in great detail (Delmotte et al. 2008, 2009; Mansouri et al. 2010; Pizzi et al. 2006). According to these studies, the amorphous wood polymers lignin 
and hemicelluloses "melt" and flow in a process termed the "un-gluing" of wood cells. This process results in the formation of an "entanglement network of molten polymers" that solidifies subsequently into a "wood fiber entanglement network composite" (Gfeller et al. 2003). Kaliyan and Morey (2009d) have recently reviewed the densification mechanisms in solid biofuels in great detail. Stelte et al. (2011d) have studied the bonding mechanism in fuels pellets made from different biomass resources in great detail. The quality of the bonding can be studied by means of compression testing and fracture surface analysis of the surfaces created at break. Both Stelte et al. (2011d) and Kaliyan and Morey (2010b) have used this technique to study the inter-particle bonding within a biomass pellet. To study the fracture surface, the pellets are coated with a conductive layer and viewed in a scanning electron microscope as shown in Fig. 9 (Stelte et al. 2011d). A rough surface (Fig. 9a) showing fiber pullouts or tear-out and polymeric flow are indications for stronger adhesion due to interpenetration of polymer chains from adjacent biomass particles. Flat fracture surfaces (Fig. 9b), on the contrary, are indicators for brittle failure mechanisms. This can be due to the presence of a weak boundary layer, i.e. hydrophobic extractives or a lack of polymeric flow as a result of too low temperature and/or moisture content (Stelte et al. 2011d). Weak boundary layers have been identified as one possible reason why straw pellets have lower mechanical properties compared to wood pellets. Straws have a high content of extractives concentrated on their outer surface (the plant cuticle), which can lead to the creation of a layer that hinders/prevents the formation of stable bonds between adjacent biomass particles during pelletizing processes (Stelte 2012a).

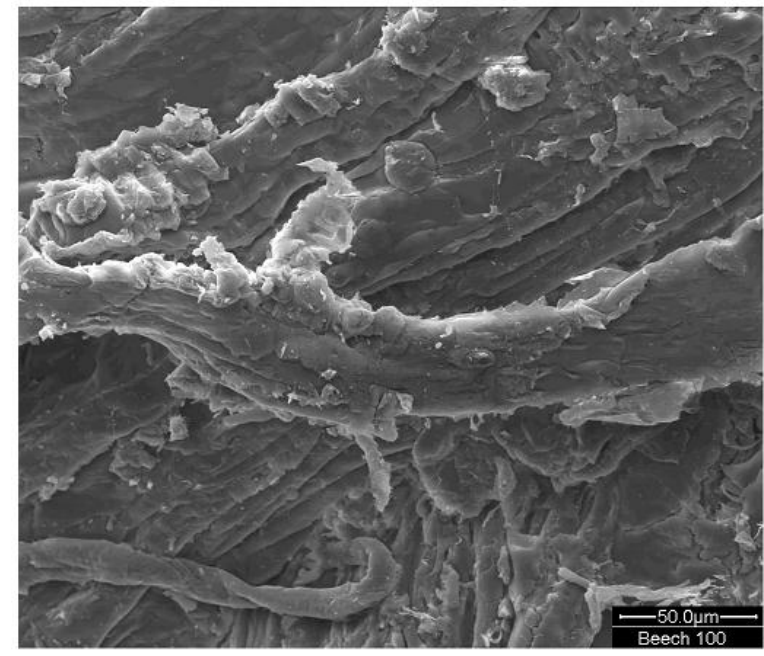

a)

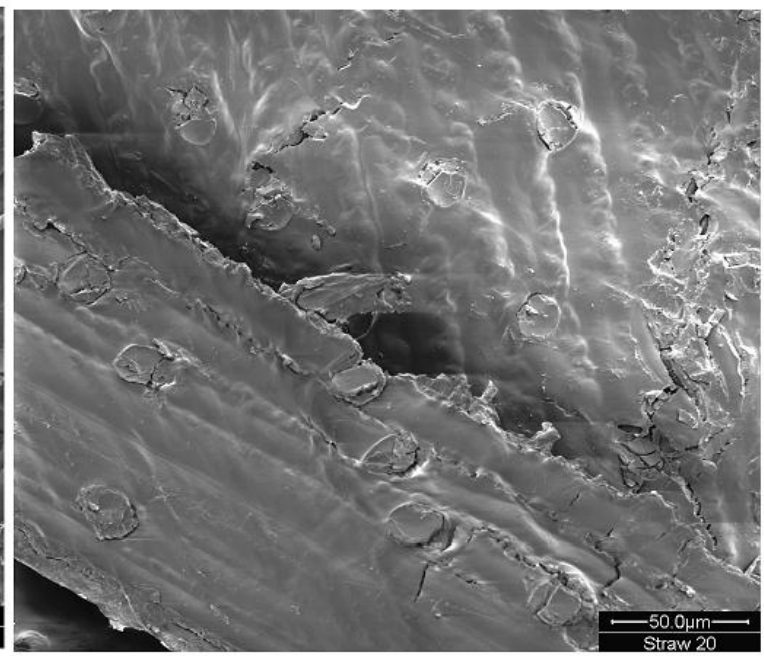

b)

Fig. 9. a) Fracture surface of a pellet showing signs of strong adhesion (i.e. rough surface polymeric flow, fiber pullouts) and b) fracture surface of a pellet showing signs of poor adhesion (i.e. brittle failure, flat surface, lack of fiber pullouts, and polymeric flow). Graphics reprinted with permission from Stelte et al. 2011d (C) Elsevier

Kaliyan and Morey (2010b) have also studied fracture surfaces of biomass briquettes using light microscopy (Fig. 10). The figures support the suggested bonding mechanisms and show indications for both polymer melting (Fig. 10a) and interlocking of fibers (Fig. 10b). 


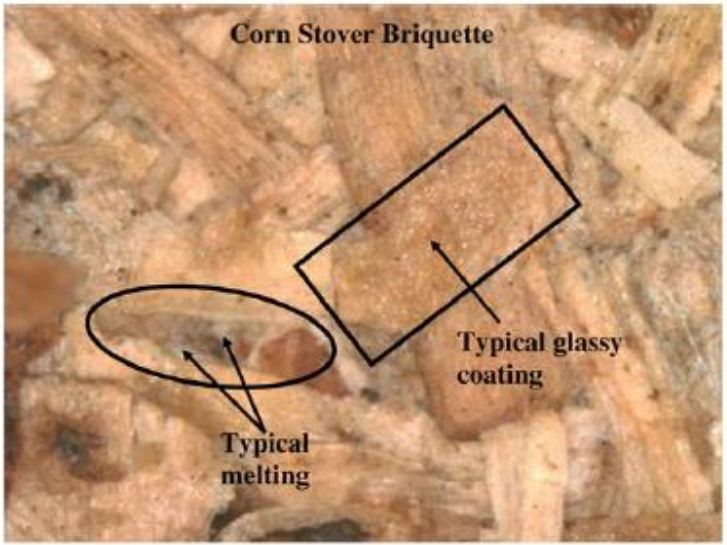

a)

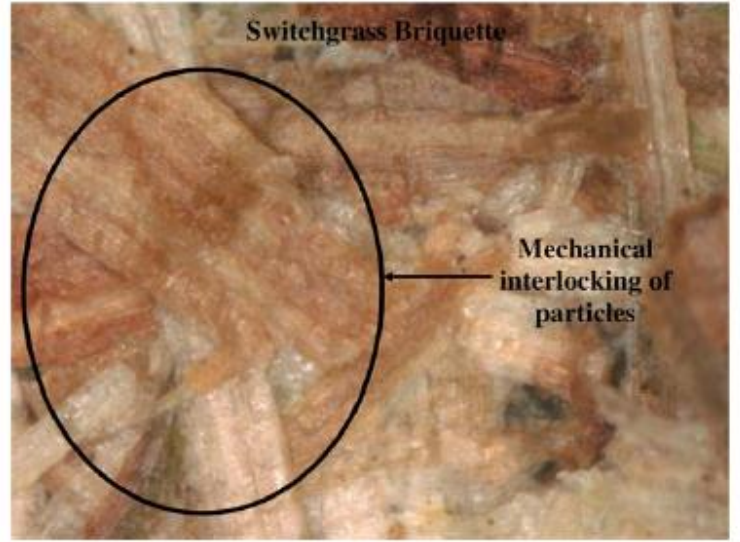

b)

Fig. 10. Light microscopy images of fracture surfaces of a) corn-stover briquettes and b) switch grass briquettes. Graphics reprinted with permission from Kaliyan 2010b (c) Elsevier.

\section{Biomass Composition and Additives}

The effect of biomass constituents on the strength and durability of feed pellets have recently been reviewed by Thomas et al. (1997), who focused on the influence of starch, protein, fiber, fat, and extractives on the biomass bonding properties. Although fuel pellets serve a different purpose and vary considerably in composition from pelletized fodder (i.e. it contains less starch, protein, and fat), a lot of valuable information can be found in this study. Starch plasticizes in the presence of heat and moisture in a process generally known as gelatinization; this gelatinization process significantly increases pellet durability (Heffner and Pfost 1973). Proteins, like starch, are known to plasticize under heat and pressure and have been shown to increase pellet strength (Briggs et al. 1999). The fiber content of biomass has to be differentiated into watersoluble and insoluble fibers. Soluble fibers generally increase the viscosity of the feed and have a positive effect on the pellet structure, while insoluble fibers can become entangled with each other (Rumpf 1962). The stiffness and resilience of a fiber can be problematic during pelletization, and large fibers can result in weak spots where pellets fragment (Thomas et al. 1998) due to stress concentration at the end of fiber clumps. The presence of lipids in pellet feedstock results in a decrease of the pellet's mechanical properties (Briggs et al. 1999), mainly due to inhibition of bonding properties of the water soluble compounds (hydrogen bonding) (Thomas et al. 1998). Results from those studies indicate the importance of thermal softening and plastic deformation, flow, and subsequent hardening of biomass polymers during pelletization.

In the case of fuel pellets from biomass, it has been shown that high extractives contents lower the friction in the press channel of a pellet mill (Nielsen et al. 2010; Stelte et al. 2011b; Stelte et al. 2012a). Furthermore it was shown that high concentrations of extractives on the biomass particle surface can reduce the mechanical strength of densified biomass products by creating a weak boundary layer, resulting in the cohesive failure of the extractive such as wax (Bikerman 1961; Bikerman 1967; Stelte et al. 2011d, 2012a).

Additives or binders may be added to improve the pellet's mechanical properties, i.e. increase density and strength, improve pelletizing throughput, or improve moisture resistance (Obernberger and Thek 2010). Another reason to include additives is to 
improve the combustion properties, e.g., ash melting point, slagging, and corrosion (Miles et al. 1996). Binders can be in liquid or solid form to improve the inter-particle bonding. Roughly 50 organic and inorganic compounds have been used in densified biomass products (Pietsch 2002). In feedstock pellets, a wide range of additives are used, including molasses, starches, proteins, modified cellulose, kraft lignins, and inorganic clay minerals (Kaliyan and Morey 2009d; Tabil 1996; Thomas et al. 1997). A very common additive for wood pellets is kraft lignins, which have recently been shown to increase the mechanical properties of wood pellets to a greater degree than starch (Nielsen et al. 2008). Other additives used in wood pellets are paraffin, molasses, stearin, and cellulose fibers (Obernberger and Thek 2010). It has to be noted that there are national differences about what additives are allowed in fuel pellets; the legislation in Denmark is, for example, more restrictive than Germany (Obernberger and Thek 2010). Stevens and Gardner (2010) have recently conducted a study investigating the effect of two lignin types on fuel value, moisture content, and quality. They concluded from their study that the procedure to prepare the lignin has a major impact on the feasibility of using lignin as an additive.

\section{Role of Lignin Glass Transition in Bonding}

The role of lignin plasticization during biomass processing has been examined in many studies in general (Back 1987; Bouajila et al. 2005; Bouajila et al. 2006; GanneChedeville et al. 2008; Mansouri et al. 2010; Olsson and Salmén 1992; Salmén and Olsson 1998), and more specifically its influence on biomass pellet stability (Kaliyan and Morey 2009b; Kaliyan and Morey 2010b; Stelte et al. 2011c,d, 2012a). With an increase in temperature, the energy of a lignin molecule increases, intermolecular bonds are weakened, and rotations around covalent bonds occur. The lignin becomes more flexible and passes from a glassy into a rubbery state. The temperature of this transition is defined as the glass transition temperature $\left(T_{g}\right)$; this temperature value depends on lignin composition and the presence of a plasticizer, i.e. water (Olsson and Salmén 1992; Salmén and Olsson 1998; Stelte et al. 2012a). Temperatures above the $T_{g}$, increase the flow of these molecules. At temperatures higher than the $T_{g}$, inter-molecular bonding is reduced, while chain mobility and free volume is increased to such an extent that polymer chain ends and backbone are able to rotate around their own axis. As a consequence, the viscosity of a polymer passing from a glassy to a plastic state drops significantly, resulting in pronounced flow characteristics, which is enhanced with externally applied pressure. Surface contact between particles is enhanced and enables the inter-penetration of polymer chain ends and segments between adjacent fibers, and the establishment of new secondary bonds and entanglements once the polymer is cooled down below the $T_{g}$ (Back 1987; Bouajila et al. 2005, 2006). The idea of a softening point is a somewhat simplified picture. In reality the transition occurs over a temperature range because biopolymers are heterogeneous materials with a diverse chemical structure, which include different types of side chains, a wide distribution of molar mass, and different chain lengths (Stelte et al. 2011d). The $T_{g}$ of lignin in wheat straw and spruce have been studied by means of dynamic mechanical thermal analysis (DMTA) (Fig. 11). The figure shows the storage modulus $\left(E^{\prime}\right)$ and loss factor $(\tan \delta)$ of dry and moist wheat straw and spruce.

At $8 \%$ moisture content, the $T_{g}$ of wheat straw lignin was at about 53 to $63^{\circ} \mathrm{C}$, while the $T_{g}$ for spruce lignin under the same conditions ( $8 \%$ moisture content) was found to be significantly higher at about $91^{\circ} \mathrm{C}$ (Fig. 11a and 11b). Under dry conditions, no 
lignin glass transitions were found for any of the tested materials (Fig. 11c and 11d). Pressing above the lignin $T_{g}$ improves the pellet's mechanical properties and reduces the friction in the press channel (Stelte et al. 2012a). Furthermore, the presence of moisture, high temperatures, and pressure increases the flow of amorphous wood polymers, such as lignin molecules, thus, enhancing the contact area and the possibility of molecular interpenetration of molecules between two particles.

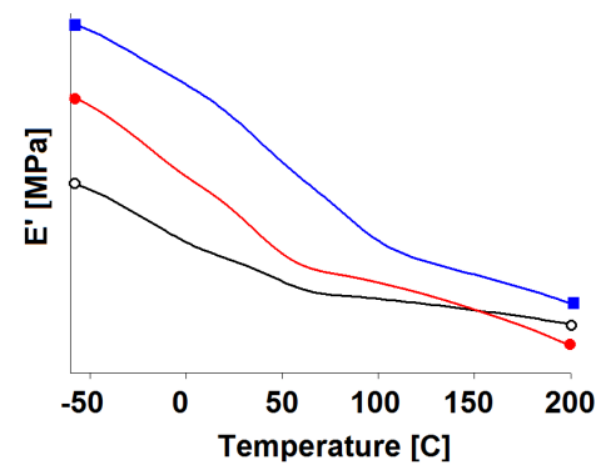

a)

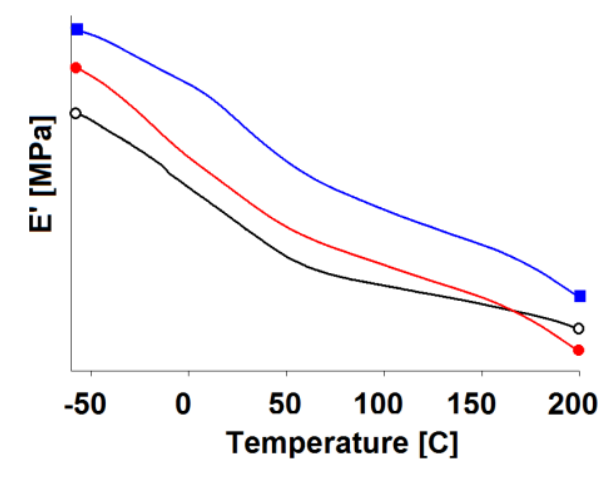

c)

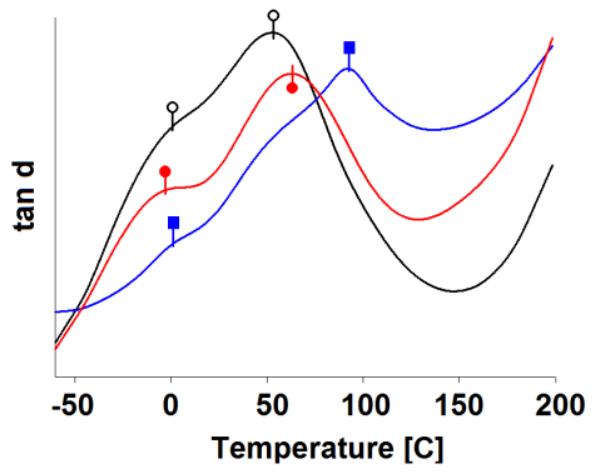

b)

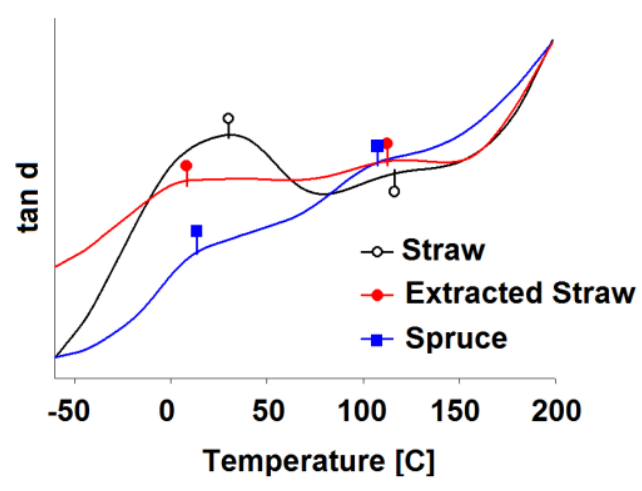

d)

Fig.11. (a) Storage modulus $(E)$ and $(b)$ loss factor $(\tan \delta)$ of straw, extracted straw and spruce. The samples moisture content were $8.4 \%, 8.3 \%$ and $9.0 \%$ for straw, extracted straw and spruce. (c) Storage modulus $(E)$ and $(d)$ loss factor $(\tan \delta)$ of dry straw, dry extracted straw, and dry spruce. It has to be noted that the scale on the y-axes ( $E$ and tan $\delta$ ) was shifted for better comparison of the samples. The absolute values for the $\tan \delta$ peaks were in all cases $<0.1$, and thus, significant. Graphics reprinted with permission from Stelte et al. 2011c (c) Elsevier.

\section{Pellet Quality and Standardization}

Customers place high demands on pellet quality, especially residential users who fire pellets in small scale furnaces in which high quality is required to enable automated and trouble-free feeding (Obernberger and Thek 2010). Biomass pellets are subject to mechanical loads and environmental factors during production, transportation, and storage; i.e. pellets are pumped into storage silos, transported by truck or ship, and delivered to the customer. During all these steps there is the risk of mechanical failure of the pellet, resulting in fines and dust formation that have shown to have harmful effects 
on human health (Hagstrom et al. 2008, Igathinathane et al. 2009). Apart from health effects, pellet producers are competing against each other, and pellet quality is a major concern for customers.

The quality of biomass pellets and briquettes, as well as raw material specification are clearly defined according to European and international standards. EN 14961-1 determines the fuel quality classes and specifications for solid biofuels in general and EN 14961-2 and 14961-3 determine the fuel quality classes and specifications of wood pellets and briquettes for non-industrial use. EN 14961-6 provides specification for pellets made from non-woody biomass. The corresponding international standards are ISO/CD 17225-1 for general specification and ISO/CD 17225-2 and ISO/CD 17225-3, which are more specific for pellets and briquettes. Non-woody biomass is covered by standard ISO/CD 17225-6. Those standards define the product quality in terms of raw materials, dimensions, moisture content, ash, mechanical durability, amount of fines, and additives included.

There are different ways to determine pellet quality. The most commonly used and standardized tests take into consideration the pellet hardness (compression strength), durability (abrasion resistance), impact resistance, and moisture uptake (Kaliyan and Morey 2009). The pellets mechanical properties depend mainly on the bonding strength between the individual biomass particles that depend on processing parameters and raw material characteristics (Stelte et al. 2011d).

The pellet hardness (or compression strength) is defined as the force at breakage when a pellet is placed between two metal plates and compressed at a fixed strain rate while force and distance are recorded (compression curves), as shown in Fig. 12.

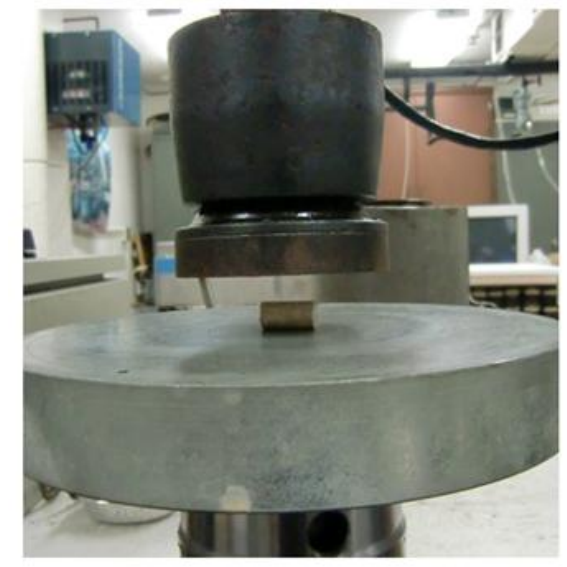

a)

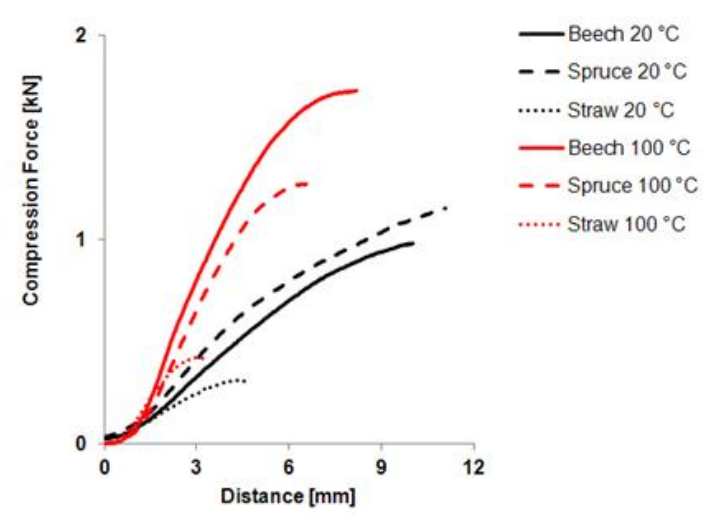

b)

Fig. 12. (a) Compression testing of pellets and (b) recorded force distance curves to determine the force at break. Reprinted with permission from Stelte et al. 2011d (C) Elsevier.

Durability or abrasive resistance is an important measure for the ability of a pellet to withstand destructive forces during handling (Kaliyan and Morey 2009). The pellet has to maintain its structure during the whole supply chain from pellet mill to customer with a minimum of fines and dust formed during the various handling steps. Pellets are often transported by pumping, conveyer belts, transport snails, or shoveling, all processes in 
which high mechanical stresses are created that might lead to pellet failure, fines, and dust formation.

Standard testing equipment for pellet durability is designed in a way that a defined mass of pellets is exposed to mechanical stresses for a defined time interval and a subsequent determination of fines formation. Mechanical stress in standard testing equipment is created either by exposing pellets to pressurized air (Holmen tester) that makes them whirl through metal pipes (similar as it might occur during the pumping of pellets from a truck into a pellet storage) or by rotational movement (tumbling can tester), where a defined mass of pellets are filled into a box of defined size (Fig. 13) and rotated for a certain time interval at a defined rate. Testing procedures are well defined according the European standards EN 15210-1 for pellets and EN 15210-2 for briquettes.

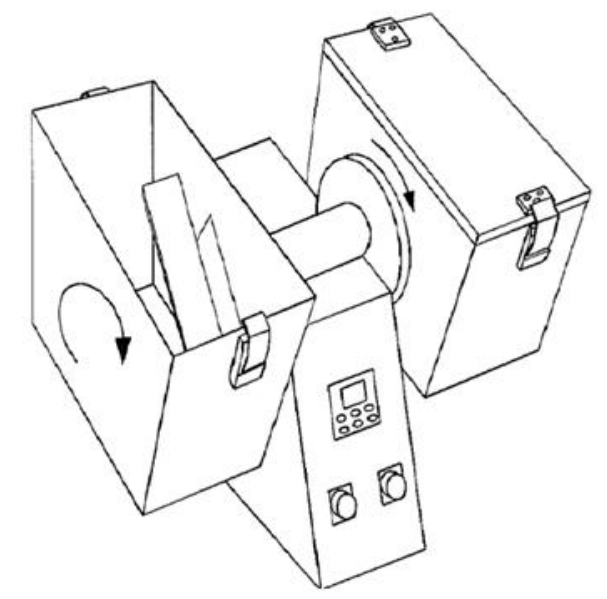

Fig. 13. Tumbling can tester for pellet durability test according to EN 15210-1

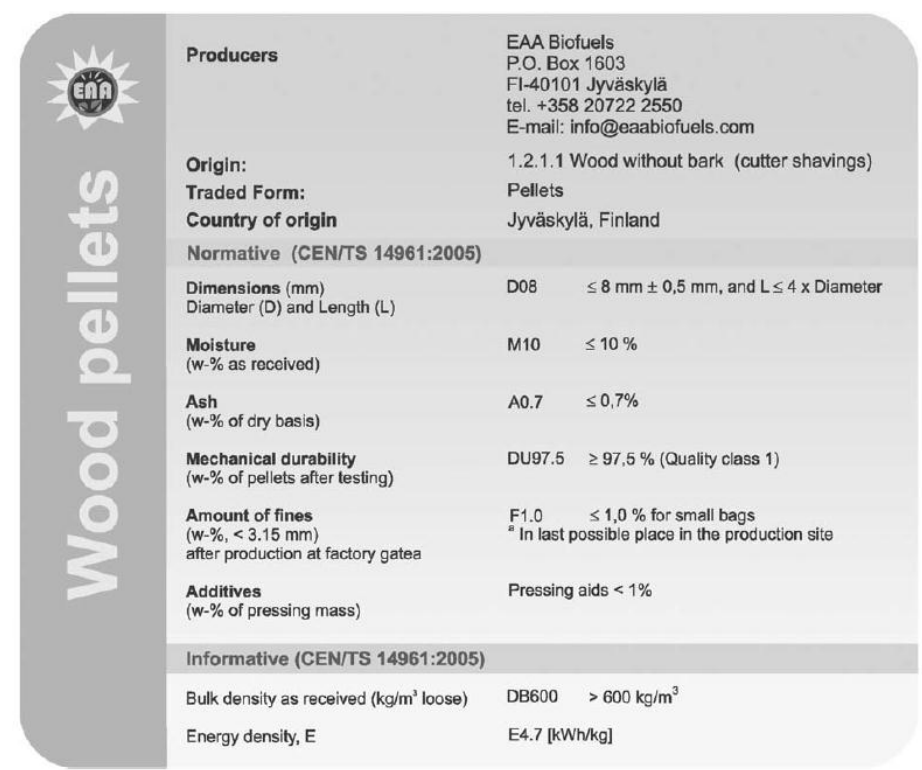

Fig. 14. Example of a fuel quality declaration (Reprinted with permission from Alakangas et al. 2006 (c) Elsevier) 
A more destructive test set up is the Ligno tester, which has been introduced by the feedstock industry. This device uses pressurized air to rapidly circulate pellets around a perforated chamber within a defined time interval. Examples on how to use these standards and their implementation have been published earlier by Alakangas et al. (2006). A good example of a fuel quality declaration based on pellet standards in shown in Fig. 14, which shows producer information, raw material, dimensions, moisture content, ash, mechanical durability, amount of fines, additive addition, density, and energy density.

\section{HEAT TREATMENT AND PELLETIZATION}

\section{Torrefaction}

Some properties of biomass are inconvenient for its utilization as fuel in combustion and gasification processes, i.e. its high oxygen contents, low calorific value, hydrophilic nature, and high moisture content (van der Stelt et al. 2011). Apart from these, its fibrous and tenacious structure, as well as its inhomogeneous composition, makes biomass even more challenging and energy-intense to process (van der Stelt et al. 2011). Numerous studies have shown that torrefaction converts biomass into a fuel with a lot more favourable properties (Acharjee et al. 2011; Arias et al. 2008; Bourgois et al. 1989; Brosse et al. 2010; Deng et al. 2009; Kiel et al. 2008; Kleinschmidt 2011; Pentananunt et al. 1990; Pimchuai et al. 2010; Prins et al. 2006a-c; Repellin et al. 2010; Yan et al. 2009). Torrefaction is a thermal pre-treatment process in which the biomass is heated up to 200 to $300^{\circ} \mathrm{C}$ in the absence of oxygen (usually under nitrogen atmosphere). The resulting product has a lower oxygen content, higher calorific value, low moisture content, and less hydrophilic compared to the untreated biomass. Furthermore, the fibrous and tenacious nature of the biomass is reduced, resulting in a brittle material that can easily be comminuted into smaller particles (van der Stelt et al. 2011).

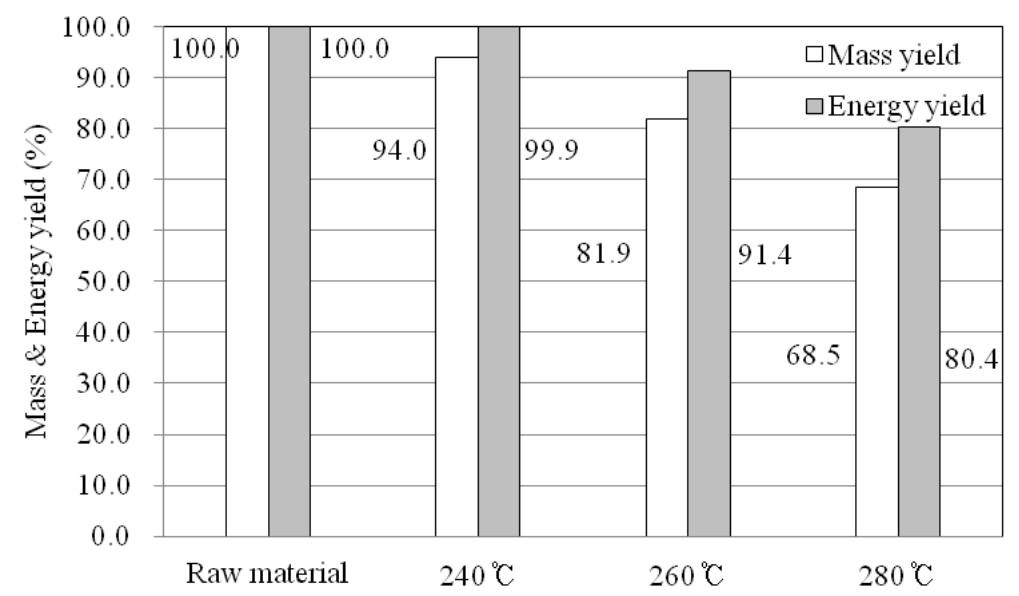

Fig. 15. Mass and energy yield for biomass torrefied at different torrefaction conditions. Reprinted with permission from Kim et al. 2012 @ Elsevier.

During torrefaction, the biomass is partly decomposed, in the process of which low molecular organic volatile compounds evaporate from the biomass (Prins et al. 2006b). This results in a decrease of mass, while the initial energy content is only reduced 
slightly. However as a consequence, the energy density of the biomass is increased, making it more attractive as a fuel (van der Stelt et al. 2011). Kim et al. (2012) have studied the mass and energy yield when torrefying yellow poplar at temperatures between 240 and $280^{\circ} \mathrm{C}$ (Fig. 15). The mass loss is greater than the energy loss, indicating that mainly volatiles of low energy density evaporate from the biomass during torrefaction.

Shang et al. (2012) have correlated the heating value of torrefied biomass with the anhydrous weight loss (AWL) and energy loss, as shown in Fig. 16.

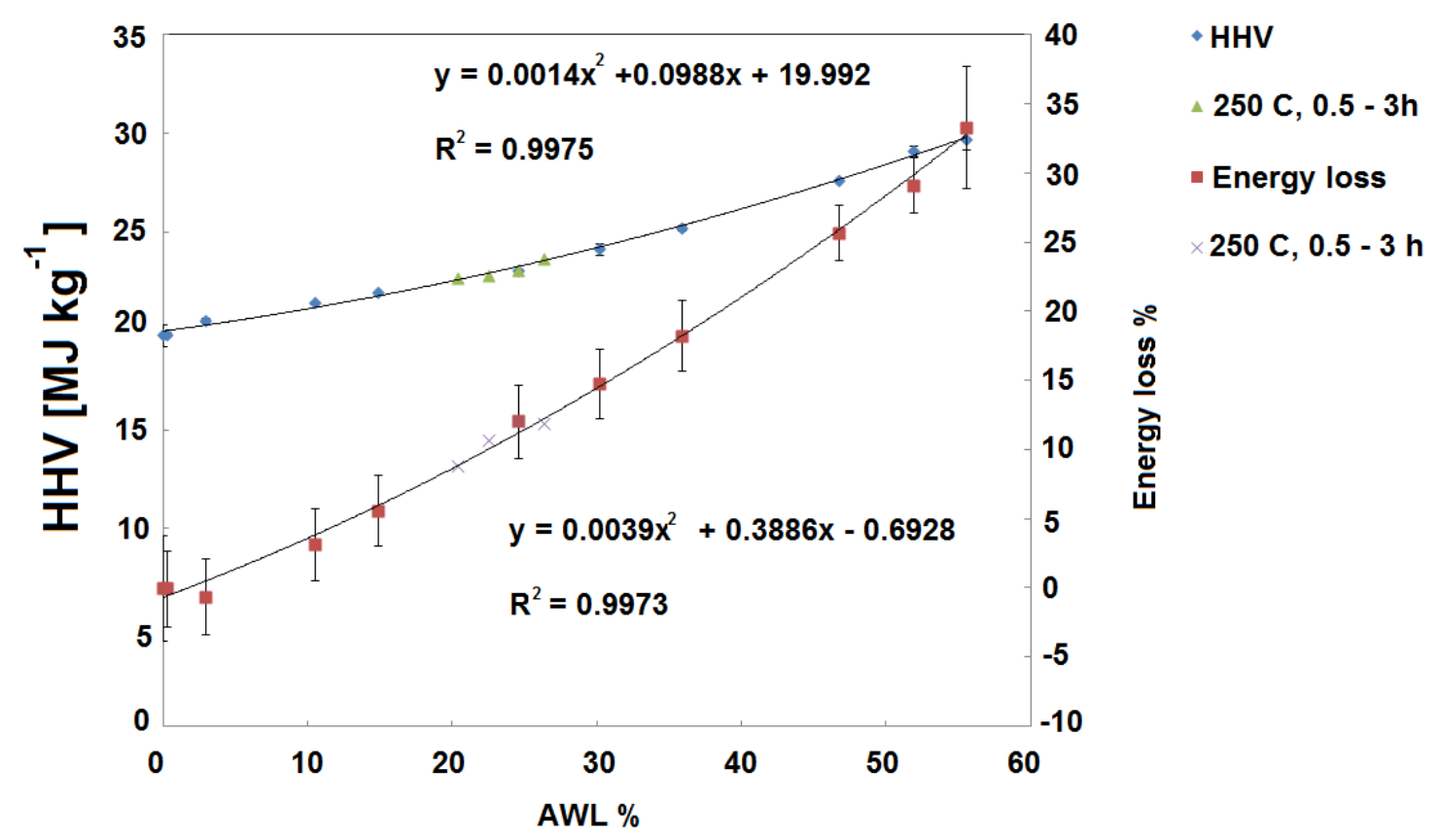

Fig. 16. Higher heating value (HHV) and percent of energy loss of wheat straw torrefied at different temperatures $\left(150,200,220,230,250,260,270,280,290,300^{\circ} \mathrm{C}\right)$ for 2 hours. The data points " $250^{\circ} \mathrm{C}, 0.5-3 \mathrm{~h}$ " represent data at $250^{\circ} \mathrm{C}$ with residence times of $0.5,1,2$, and 3 hours. The $x$-axes shows the anhydrous weigh loss (AWL) and the red bricks correspond to the increase in torrefaction temperature $\left(150,200,220,230,250,260,270,280,290,300^{\circ} \mathrm{C}\right)$. Reprinted with permission from Shang et al. 2012 (c) Elsevier.

Torrefaction is used to convert various types of lignocellulosic biomass into an energy-dense homogeneous solid. The volatiles can be subdivided into condensable and non-condensable compounds. Condensable compounds are mainly water and organic acids, while non-condensables consist mainly of carbon monoxide and carbon dioxide (Prins et al. 2006b). Furthermore, biomass polymers, i.e. hemicelluloses, cellulose, and lignin, are degraded and/or transformed (Melkior et al. 2012). The most reactive compounds are hemicelluloses. Xylan was found to decompose quickly at about $200^{\circ} \mathrm{C}$, resulting in high weight loss of the biomass. Cellulose degradation starts slowly at about $270^{\circ} \mathrm{C}$, but accelerates noticeably at temperatures above $300^{\circ} \mathrm{C}$ (Prins et al. 2006a). Rousset et al. (2009) have studied the thermal degradation of lignin under torrefaction in great detail and concluded that lignins are more resistant to prolonged heat treatment than polysaccharides, and that lignin undergoes intense structural transformations during torrefaction, mainly cleavage and recondensation reactions. Shang et al. (2012) have studied the chemical changes during torrefaction of wheat straw at temperatures between 150 and $300^{\circ} \mathrm{C}$ by means of attenuated total reflectance Fourier transform infrared 
spectroscopy (ATR-FTIR). The spectra (Fig. 17) shows a degradation of hemicelluloses at relatively low torrefaction temperatures (starting at $250^{\circ} \mathrm{C}$ ). Indications of the degradation of hemicelluloses is the gradual decrease of the carbonyl stretching band of carboxylic acid groups of hemicelluloses at $1732 \mathrm{~cm}^{-1}$ and the decrease of a band at 900 $\mathrm{cm}^{-1}$ that can be assigned to xylan, a major building block of hemicelluloses.

Bands assigned to cellulose $\left(670\right.$ and $\left.1160 \mathrm{~cm}^{-1}\right)$ decrease at temperatures above $270^{\circ} \mathrm{C}$. Bands assigned to lignin $\left(1505 \mathrm{~cm}^{-1}\right)$ remain stable over the whole temperature range (Shang et al. 2012).

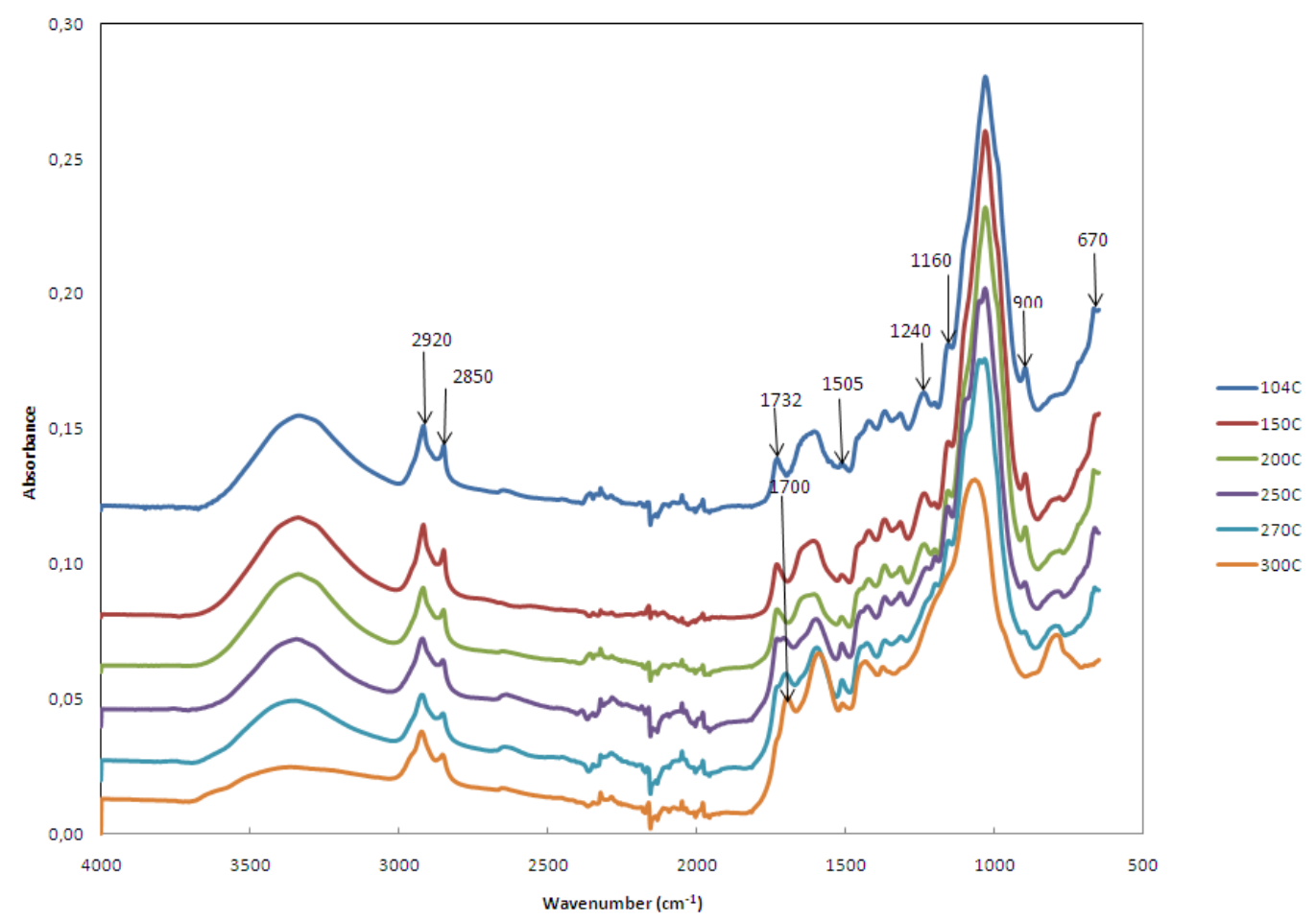

Fig. 17. ATR-FTIR spectra of oven dried $\left(104^{\circ} \mathrm{C}\right)$ and torrefied wheat straw samples. All spectra are separated to ease comparison. Reprinted with permission from Shang et al. 2012 @ Elsevier.

Stelte et al. (2012b) conducted a standard fiber analysis of wheat straw torrefied at temperatures between 150 and $300^{\circ} \mathrm{C}$ in $50^{\circ} \mathrm{C}$ intervals (termed T150, T200, T250, T300). Their results support the finding that hemicelluloses are degrading at low temperatures, while cellulose and lignin (insoluble fraction) are more stable. The data are shown in Table 2. The high amount of insoluble residues for the T300 sample is probably due to thermal degradation products that interfered with the procedure used to quantify the lignin concentration (Yan et al. 2009).

Table 2. Fiber Analysis of Torrefied Wheat Straw (Data from Stelte et al. 2012b)*

\begin{tabular}{|l|l|l|l|l|l|}
\hline Sample & Cellulose & Hemicellulose & Insoluble fraction & Ash & Yield [\%DM] \\
\hline Straw & $37.2 \pm 0.3$ & $27.3 \pm 0.4$ & $19.2 \pm 0.5$ & $4.9 \pm 0.2$ & 100 \\
\hline T150 & $36.4 \pm 0.4$ & $27.1 \pm 0.5$ & $19.1 \pm 0.6$ & $5.5 \pm 0.3$ & 99.7 \\
\hline T200 & $36.7 \pm 0.4$ & $26.1 \pm 0.2$ & $20.7 \pm 0.5$ & $5.4 \pm 0.2$ & 96.8 \\
\hline T250 & $37.5 \pm 0.2$ & $5.8 \pm 0.1$ & $47.2 \pm 0.3$ & $6.7 \pm 0.4$ & 74.7 \\
\hline T300 & $1.4 \pm 0.2$ & $4.6 \pm 0.3$ & $>80$ & $10.7 \pm 0.4$ & 45.9 \\
\hline
\end{tabular}

* ' $T$ ' indicates torrefied and the number after that is the temperature of torrefaction. 
A detailed analysis about the chemical changes during biomass torrefaction has recently been published by Kim et al. (2012), where they studied the torrefaction process of yellow poplar. They conducted a fiber analysis and studied the condensate fraction as well as analyzed the elemental composition and inorganic compounds at different torrefaction conditions. They found that hemicellulose contained in torrefied biomass decreased with an increase in torrefaction temperature $\left(240\right.$ to $280^{\circ} \mathrm{C}$ and 30 minutes reaction time); they observed only slight effects on the cellulose and lignin content in the biomass.

Torrefaction improves the combustion properties, since higher combustion rates can be achieved while reducing smoke emissions at the same time. Different studies have been conducted to investigate the grinding of torrefied wood (Pentananunt et al. 1990; Arias et al. 2008; Repellin et al. 2010; Shang et al. 2012). Both grinding energy and product particle size were decreased with torrefaction. The biomass gets completely dry during torrefaction. Due to the degradation of the carbohydrate polymers (dehydration reactions), most of the hydroxyl groups that can act as bonding sites for water are removed from the biomass. Hence, the hygroscopic nature of biomass is partly lost (Bergman 2005). Stelte et al. (2011a) investigated the water uptake of torrefied spruce by exposing it to 250,275 , and $300^{\circ} \mathrm{C}$ air with a relative humidity of 65,75 , and $90 \%$. The results summarized in Fig. 18 show that torrefied spruce absorbs less water than untreated wood.

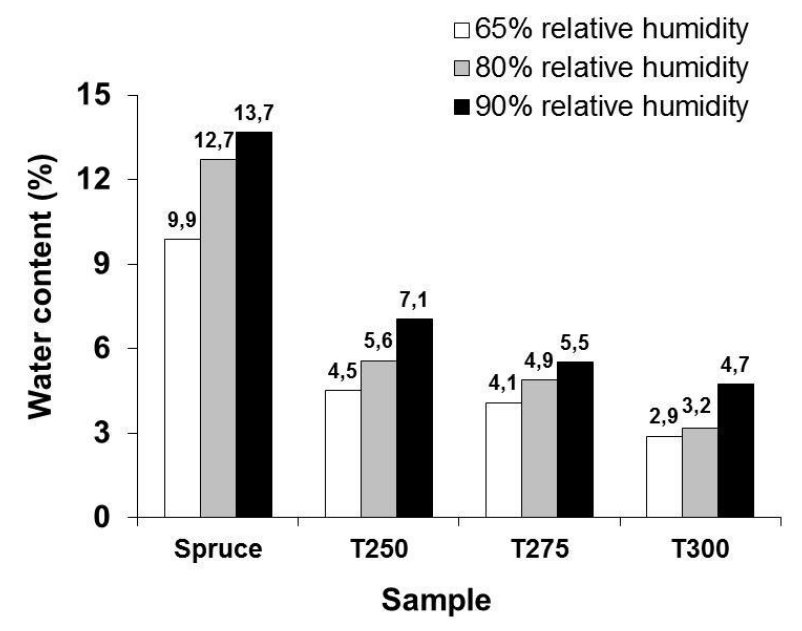

Fig. 18. Moisture content of spruce and torrefied spruce after three weeks of storage in climate chambers at 65,80 , and $90 \%$ relative humidity and $27^{\circ} \mathrm{C}$. Reprinted with permission from Stelte et al. 2011a @ Elsevier.

\section{Pelletization of Torrefied Biomass}

Recently, torrefaction has been combined with pelletization to produce a biofuel with "coal like" properties; this process is advantageous when it comes to substitution and/or supplementation of coal with biomass in coal-based power plants. Main advantages are better grinding properties and storage properties when compared to conventional wood pellets. Torrefied pellets contain less moisture, have a higher heating value, and are less sensitive to moisture uptake and biological degradation (i.e. fungi and bacteria). Furthermore they can be ground into a dust like powder using conventional 
coal mills while wood pellets require a special mill and higher energy input for grinding (Kleinschmidt 2011).

So far only a few studies have been published about the pelletizing properties of torrefied biomass (Bergman 2005; Gilbert et al. 2009; Li et al. 2012, Pirraglia et al. 2012, Stelte et al. 2011a, 2012b; van der Stelt et al. 2011). There are somewhat opposing opinions on whether torrefaction has a positive or negative effect on pelletizing properties and quality.

Some studies claim that torrefaction improves the mechanical properties of the biomass pellets because of its high lignin content (due to thermal degradation of hemicelluloses and cellulose) (Kiel et al. 2008; van der Stelt et al. 2011), while other studies indicate that the mechanical properties of pellets obtained from torrefied biomass are lower (Gilbert et al. 2009; Li et al. 2012, Stelte et al. 2011a). It has been shown earlier that the thermal softening of lignin and its subsequent flow results in interpenetration of amorphous polymer molecules between adjacent biomass particles, and this is likely to have a great effect on pellet strength (Stelte et al. 2011d, 2012a).

Nevertheless, a high lignin content does not necessarily mean better bonding, especially since the low moisture content of the biomass has been shown to influence the softening temperature of the lignin, and as such, the bonding properties of the biomass (Stelte et al. 2011c). Some studies indicate that the softening temperatures of dry lignin are well above the typical temperatures reached in the pelletizing processes (Kelley et al. 1987; Olsson and Salmen 1992).

There are studies regarding the pelletizing process which suggest that torrefaction significantly reduces the energy used for pelletization due to the reduced energy required for grinding the material and lower pressures required for pelletization (Bergman 2005). On the other hand, another study indicated increased friction within the press channels of a mill when pelletizing torrefied biomass (Stelte et al. 2011a), likely due to the absence of lubricating extractives and amorphous polymer molecules. The results indicate that the friction in the press channel of a pellet mill increases with an increase in torrefaction temperature and that the pellet's mechanical properties and density decrease with an increase in torrefaction temperature. This is possibly due to less extractives and polymer molecules being present on the surface. Li et al. (2012) reported significantly higher energy consumption for compaction and extrusion processes of torrefied sawdust from spruce and fir compared to untreated material. They explained the increase as due to a decrease of particle plasticity during torrefaction due to thermal decomposition of lignin and hemicelluloses into organic acids, sugars, and charcoal.

Decreasing the mechanical properties of the torrefied biomass can be beneficial when it comes to comminuting biomass pellets to dust prior firing, i.e. conventional coal mills might suffice. Lower pellet stability may result in problems during transport and handling due to the formation of dust and fines. Therefore, a compromise between good grinding properties and sufficient stability during pellet handling has to be found. Studies (Stelte et al. 2011a, 2012b) indicate that torrefaction temperatures of about $250^{\circ} \mathrm{C}$ result in stable pellets of high energy density and favorable mechanical properties during size reduction and milling processes. Increase in the torrefaction temperature increased the amounts of defects, as shown in Fig. 19; torrefaction temperatures higher than $250^{\circ} \mathrm{C}$ results in a material where pellets cannot be formed. 


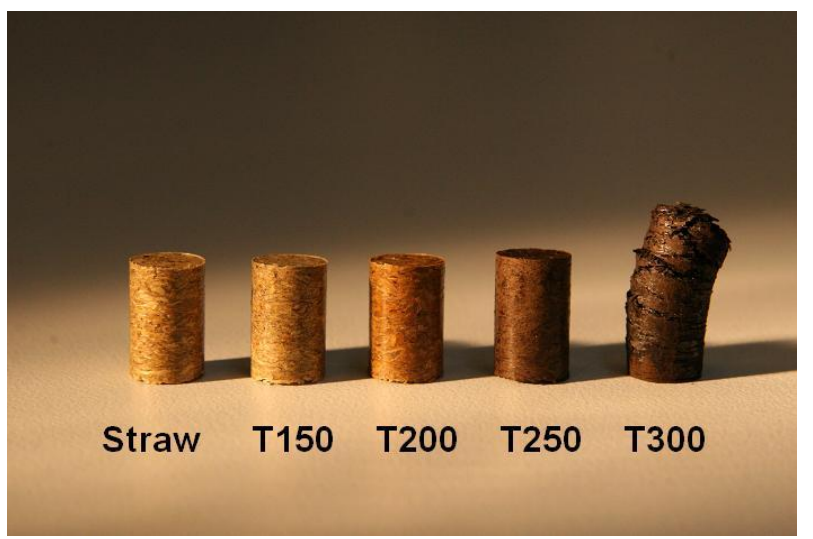

Fig. 19. Pellets made from torrefied wheat straw. From left to right: Untreated straw and torrefied straw at $150,200,250$ and $300^{\circ} \mathrm{C}$ (Reprinted from Stelte et al 2012b).

In another study (Stelte et al. 2011a), the compression strength of the pellets made from spruce torrefied at 250,275 , and $300^{\circ} \mathrm{C}$ were compared among each other and to untreated spruce (Fig. 20). The results indicated that the compression strength decreases with an increase in torrefaction temperature. At very high torrefaction temperatures $\left(300^{\circ} \mathrm{C}\right)$, it was not possible to pelletize the obtained biomass.

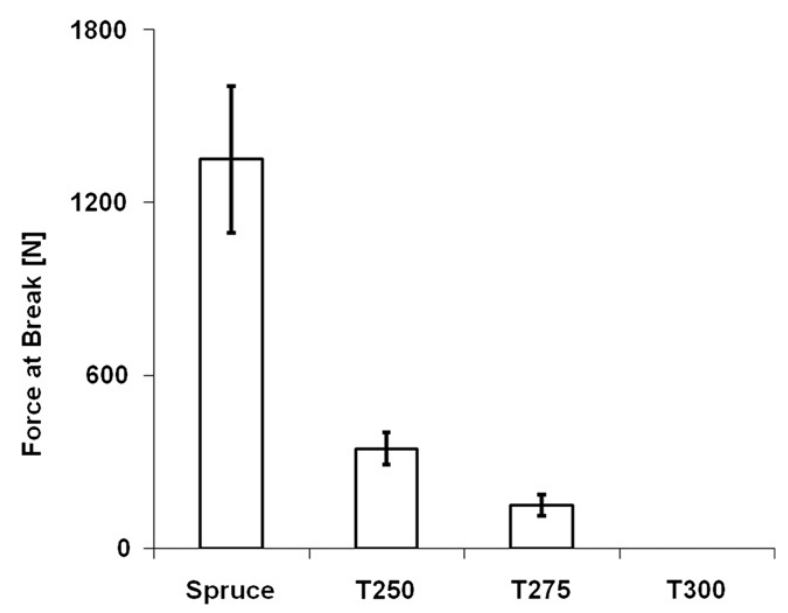

Fig. 20. Compression strength of spruce pellets compared to pellets made from torrefied spruce. Reprinted with permission from Stelte 2011a @ Elsevier.

Li et al. (2012) studied the pelletizing properties of torrefied sawdust made from a mixture of spruce and fir. The authors report both a decrease of pellet density and Meyer hardness for pellets made from torrefied wood. Density and hardness decrease with an increase in torrefaction temperature, as shown in Fig. 21.

Apart from the torrefaction temperature, time seems to be a crucial factor. The combination of torrefaction temperature and time influence the final biomass composition and thereby influence its pelletizing properties. Nordwaeger et al. (2010) conducted a parametric study of pilot-scale biomass torrefaction and found that the torrefaction temperature generally affects the properties of the product more than the torrefaction time. 

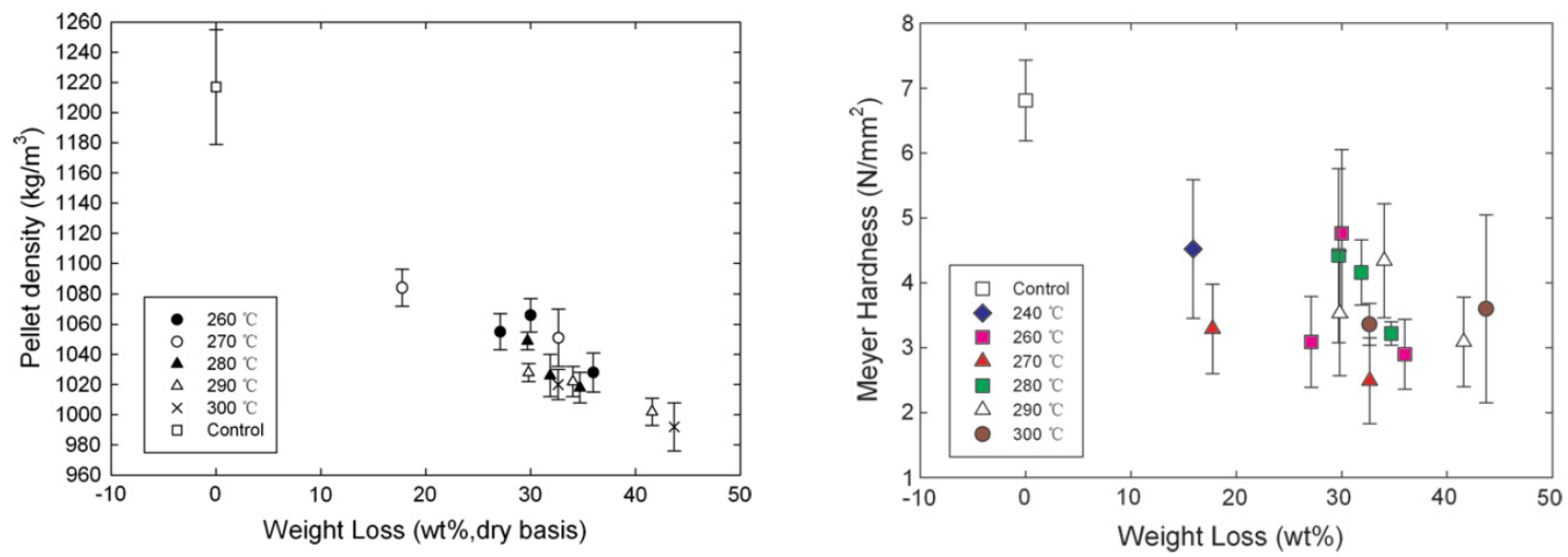

Fig. 21. a) Pellet density of pellets pressed from torrefied sawdust as a function of weight loss and torrefaction temperature. b) Meyer hardness of torrefied pellets as a function of torrefaction temperature and residence time. Reprinted with permission from Li et al. 2012 @ Elsevier.

\section{Other Heat Treatment Methods}

Alternative heat treatment processes have also been considered. A recent study by Lam et al. (2011) suggests that steam explosion of wood results in a material with favorable fuel properties (high heating value, low moisture absorption) and good pelletizing properties. Their manufactured pellets do not show any defects (Fig. 22) and pellet density increases. Similar results have been obtained by Biswas et al. (2011) who studied the pelletizing properties of steam exploded Salix. It was found that steam explosion treatment reduced the amount of alkali metals in the biomass, and the pressed pellets showed an increased density, impact and abrasion resistance. Nevertheless, small decreases in ash fusion characteristics and char reactivity was reported for elevated temperatures and residence times.

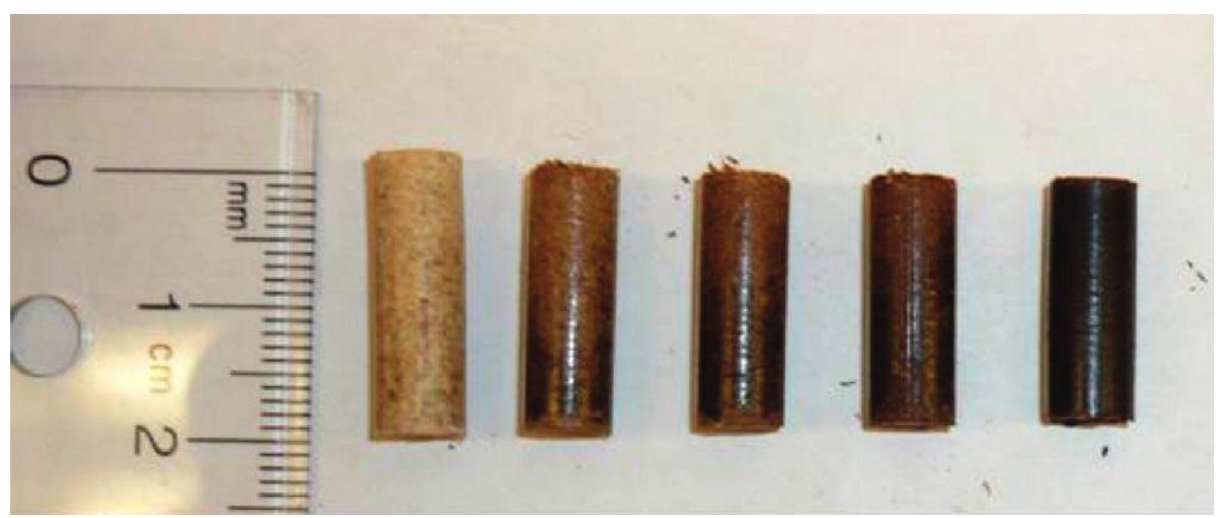

Fig. 22. Physical appearance of wood pellets treated at different steam explosion conditions. From left to right: untreated, $200^{\circ} \mathrm{C}$ for $5 \mathrm{~min}, 200^{\circ} \mathrm{C}$ for $10 \mathrm{~min}, 220^{\circ} \mathrm{C}$ for $5 \mathrm{~min}$, and $220^{\circ} \mathrm{C}$ for 10 min. Reprinted with permission from Lam et al. 2011 (c) American Chemical Society.

Reza et al. (2012) have used hydrothermal carbonization (HTC) as a pretreatment process for making pelletized biomass more homogeneous and energy dense. HTC is a process where biomass is treated with hot compressed water in the temperature range between 200 and $260^{\circ} \mathrm{C}$. The resulting biomass had an increased lignin content that acted 
as binder in the subsequent pelletization step. The resulting pellets had a higher energy and mass density and favorable physical properties (i.e. moisture resistance, mechanical stability). The pellet surface was studied by means of scanning electron microscopy and compared to pellets made from untreated and (dry) torrefied samples. It was shown that the pellets made from untreated and HTC treated biomass had a more compact structure and exhibited good inter-particle bonding. Pellets made from torrefied biomass showed cracks and had inferior mechanical properties. HTC treatment involves pressurized conditions and thus the process equipment is more costly and complicate compared to conventional torrefaction reactors (Hoeckman et al. 2011). Therefore, it is necessary to have a close look on mass and energy balances of the process and to investigate whether the material properties justify higher operation and investment costs. Hoeckman et al. (2011) suggest that a two-step HTC process involving low- and high-temperature treatment might both maximize the recovery of sugars and the production of an energy dense biomass char.

\section{OUTLOOK}

The primary future issues in biomass pellet production are the sustainable and price-competitive production of pellets for a growing industrial and domestic pellet market, which place high demands on pellet quality and combustion properties. Current trends are to combine the torrefaction and pelletization processes, and to introduce a broader base of raw materials, i.e. agricultural residues, energy grasses, and mixed biomass resources. Pretreatment processes, such as torrefaction, unify the biomass and result in a more homogeneous product, compared to what is used as raw materials. Therefore, it might be an ideal pre-treatment for utilizing different biomass types, without the need of adapting the pelletizing process to the different raw materials used. However, the pelletization of torrefied biomass is not straightforward, and this increases the processes complexity. There have been some major breakthroughs of European and North American pellet producers recently, and large-scale production of torrefied pellets has just begun on a commercial scale. Future research has to focus on the optimization of the torrefaction and pelletization parameters, focusing on which technology is more costcompetitive and how is it best implemented in a sustainable biomass supply chain.

A global pellet market requires global standards for biomass production, as well as for pellet quality. The definition of global sustainable criteria is particularly important, since it will have a great impact on how biomass is produced and harvested, and whether it can contribute positively to the reduction of greenhouse gas emissions and conserving ecosystems.

\section{Techno-Economic Evaluation of Biomass Pelletization and Torrefaction Processes}

Different studies have been made to evaluate biomass pre-treatment technologies, i.e. pelletization and torrefaction, relative to supply chain logistics and costs (Pirraglia et al. 2010; Chiueh et al. 2012; Karkania et al. 2012; Robbins et al. 2012, Shah et al. 2012, Uslu et al. 2012). General concerns and arguments against biomass for energy are that the conversion efficiency for biomass is low compared to fossil fuels; this is due to its low density and high moisture content. Nevertheless, it has been shown that the fuel 
quality of biomass can be improved by thermal and mechanical pre-treatment, which increases its fuel value (Robbins et al. 2012). Uslu et al. (2012) conclude from their study about biomass pre-treatment technologies that well-designed supply chains make international trade of biomass feasible from an energetic and economic view point.

Chiueh et al. (2012) made a case study evaluating the impact of torrefaction on cost and carbon emissions for rice straw in Taiwan. They concluded that feedstock transportation from its source to pre-treatment and co-firing stations contributed the most to the logistical costs, regardless of whether torrefaction was adopted. Shah et al. (2012), who made a techno-economic analysis of a production scale torrefaction system for biomass upgrading, state that torrefaction has to take place "early" in the biomass supply chain to be most effective. They have conducted a detailed mass and energy balance of the torrefaction processes and quantified the sensitivity of energy and cost to feedstock type, moisture content, torrefaction process parameters, and initial capital investment. Karkania et al. (2012) studied the market for agricultural pellets in Greece. They conclude from their studies that densification of biomass is an opportunity to make biomass easier to handle, but the cost factor remains a challenge. A system that can be operated all year round on different raw materials was suggested as a promising solution, i.e. the production of blended biopellets (from multiple raw material blends) is considered to have many prospects for the future. Pirraglia et al. (2010) have made an extensive techno-economic analysis of wood pellets production in the United States and developed a techno-economic model for the determination of production costs based on the most important technical and financial factors affecting pellet production. Based on their case studies, they conclude that biomass and labor costs are the most important cost drivers for the wood pellets industry, followed by energy consumption, especially when drying of the biomass is required (drying accounts for approximately $70 \%$ of the total energy consumption of the plant) (Fig 23).

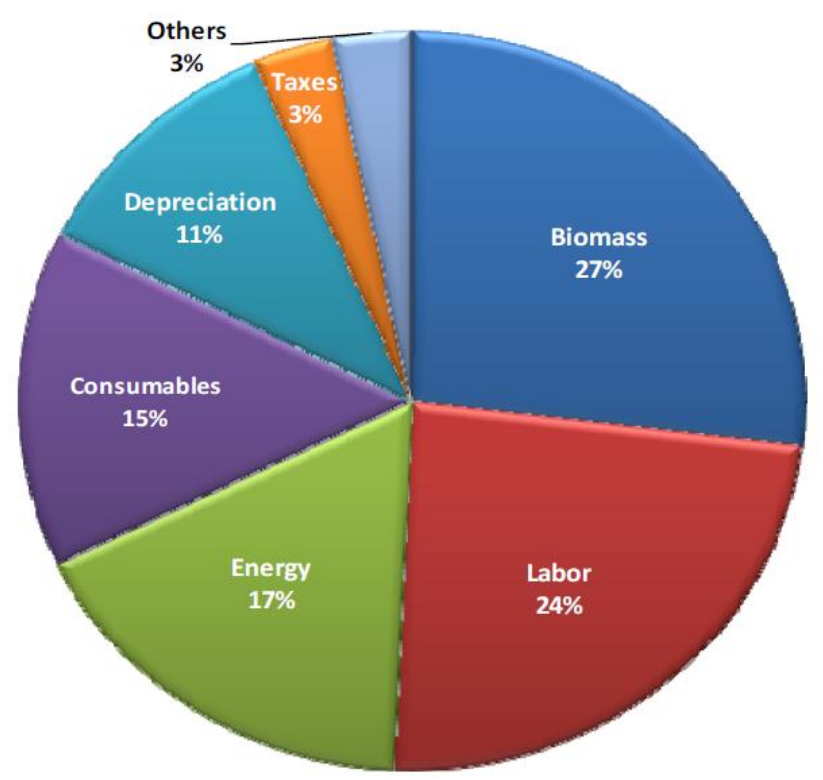

Fig. 23. Share costs of wood pellets per metric ton (reprinted with from Pirraglia et al. 2010, BioResources, NC State University) 
A similar study was made by Shah et al. (2012) concerning production-scale torrefaction units. They have developed a model to simulate the mass and energy balance and used it to determine the effect of different process parameters on energy balance, product dry matter, and costs. Major conclusions from their study were that the product dry matter yield decreases with an increase in raw material initial moisture content and torrefaction temperature. Especially, a high moisture content of the raw material was shown to have a negative impact, since it increased the net energy required for the process while decreasing the energy efficiency of the torrefaction system at the same time. Cost sensitivity analysis has shown that process costs had increasing trends with an increase in initial moisture content of the biomass, increase in torrefaction temperature, decrease in plant operating window, and initial capital investment.

\section{ACKNOWLEDGEMENT}

The present study was conducted under the framework of the Danish Energy Agency's EFP project: “Advanced understanding of biomass pelletization” ENS-330330227. The authors wish to thank Vattenfall AB, DONG Energy A/S, and the Danish Energy Agency for funding.

\section{REFERENCES CITED}

APX-ENDEX (2012). "ENDEX industrial wood pellet pricing," APX-ENDEX, (http://www.apxendex.com), Data from May 2012.

Acharjee, T. C., Coronella, C. J., and Vasquez, V. R. (2011). "Effect of thermal pretreatment on equilibrium moisture content of lignocellulosic biomass," Bioresour. Technol. 102(7), 4849-4854.

Adapa, P. K., Tabil, L. G., Schoenau, G. J., Crerar, B., and Sokhansanj, S. (2002). "Compression characteristics of fractionated alfalfa grinds," Powder Handl. Process. 14(4), 252-259.

Adapa, P., Tabil, L., and Schoenau, G. (2009). "Compaction characteristics of barley, canola, oat and wheat straw," Biosystems Eng.104(3), 335-344.

Alakangas, E., and Paju, P. (2002). "Wood pellets in Finland, technology, economy and market," OPET 5 Report, VTT Technical Research Centre of Finland, Jyväskyla.

Alakangas, E., Valtanen, J., and Levlin J.-E. (2006). "CEN technical specification for solid biofuels - Fuel specification and classes," Biomass Bioenergy 30(11), 908-914.

Alakangas, E. (2010). "New European pellets standards," Proceedings of the World Sustainable Energy Days, European Pellets Conference, 3-4 March 2010, Wels. Energiesparverband Oberösterreich, Linz.

Andreiko, D., and Grochowicz, J. (2007). "Effect of the moisture content on compression energy and strength characteristic of lupine briquettes," J. Food Eng. 83(1), 116-120.

Arias, B., Pevida, C., Fermoso, J., Plaza, M. G., Rubiera, F., and Pis, J. J. (2008). "Influence of torrefaction on the grindability and reactivity of woody biomass," Fuel Process. Technol. 89(2), 169-175.

Arrieche, R., van Dyk, H., Saloni, D., and Lemaster, R. (2011). "Evaluation of the energy balance for the production of briquettes from biomass," Forest Prod J 61(4), 302-309. 
Arshadi, M., Gref, R., Geladi, P., Dahlqvist, S., and Lestander, T. (2008). "The influence of raw material characteristics on the industrial pelletizing process and pellet quality," Fuel Process. Technol. 89(12), 1442-1447.

Back, E. L. (1987). "The bonding mechanism in hardboard manufacture - Review report," Holzforschung 41(4), 247-258.

Bauen, A., Berndes, G., Junginger, M., Londo, M., Vuille, F., Ball, R., Bole, T., Chudziak, C., Faaij, A., and Mozaffarian, H. (2009). Bioenergy - A Sustainable and Reliable Energy Source: A Review of Status and Prospects, International Energy Agency, Paris.

Bergman, P. C. A. (2005). Combined Torrefaction and Pelletization: The TOP Process, Energy Centre of The Netherlands, Petten.

Berner, R. A. (2003). "The long-term carbon cycle, fossil fuels and atmospheric composition," Nature 426(6964), 323-326.

Bikerman, J. J. (1961). The Science of Adhesive Joints, Academic Press, New York.

Bikerman, J. J. (1967). "Causes of poor adhesion - weak boundary layers," Ind. Eng. Chem. 59(9), 40-44.

Biswas, A. K., Yang, W., and Blasiak, W. (2011). "Steam pretreatment of Salix to upgrade biomass fuel for wood pellet production," Fuel Process. Technol. 92(9), 1711-1717.

Bouajila, J., Limare, A., Joly, C., and Dole, P. (2005). "Lignin plasticization to improve binderless fiberboard mechanical properties," Polym. Eng. Sci. 45(6), 809-816.

Bouajila, J., Dole, P., Joly, C., and Limare, A. (2006). "Some laws of a lignin plasticization," J. Appl. Polym. Sci. 102(2), 1445-1451.

Bourgois, J., Bartholin, M. C., and Guyonnet, R. (1989). "Thermal-treatment of wood Analysis of the obtained product," Wood Sci. Technol. 23(4), 303-310.

Briggs, J., Maier, D., Watkins, B., and Behnke, K. (1999). "Effect of ingredients and processing parameters on pellet quality," Poult. Sci. 78(10), 1464-1471.

Brosse, N., El Hage, R., Chaouch, M., Petrissans, M., Dumarcay, S., and Gerardin, P. (2010). "Investigation of the chemical modifications of beech wood lignin during heat treatment," Polym. Degrad. Stab. 95(9), 1721-1726.

Butler, J. L., and McColly, H. F. (1959). "Factors affecting the pelleting of hay," Agri. Eng. 40, 442-446.

Carone, M. T., Pantaleo, A., and Pellerano, A. (2011). "Influence of process parameters and biomass characteristics on the durability of pellets from the pruning residues of Olea europaea L," Biomass Bioenergy 35(1), 402-410.

Chen, N., Ren, J., Zhan, P., and Xu, Z. (2011). "Effect of process parameters on solid fuel briquette of rice and soybean Straw," Adv. Mat. Res. 156-157, 94-97.

Chiueh, P.-T., Lee, K.-C., Syu, F.-S., and Lo, S.-L. (2012). "Implications of biomass pretreatment to cost and carbon emissions: Case study of rice straw and Pennisetum in Taiwan," Bioresour. Technol. 108, 285-294.

Choi, Y., Kim, J., and Cha, D. (2009). "Comparison of efficiency for wood fuels (chips and pellets) by life cycle assessment," J. Korean For. Soc. 98(4), 426-434.

Coates, W. (2000). "Using cotton plant residue to produce briquettes," Biomass Bioenergy, 18(3), 201-208.

Cocchi, M., Nikolaisen, L., Junginger, M., Goh, C. S., Heinimö, J., Bradley, D., Hess, R., Jacobson, J., Ovard, L. P., and Thrän, D. (2011). Global Wood Pellet Industry Market and Trade Study, International Energy Agency, Paris. 
Čolović, R., Vukmirović, D., Matulaitis, R., Bliznikas, S., Uchockis, V., Juškienė, V., and Lević, J. (2010). "Effect of die channel press way length on physical quality of pelleted cattle feed," Food Feed Res. 37(1), 1-6.

Delmotte, L., Ganne-Chedeville, C., Leban, J. M., Pizzi, A., and Pichelin, F. (2008). "CPMAS C-13 NMR and FT-IR investigation of the degradation reactions of polymer constituents in wood welding," Polym. Degrad. Stab. 93(2), 406-412.

Delmotte, L., Mansouri, H. R., Omrani, P., and Pizzi, A. (2009). "Influence of wood welding frequency on wood constituents chemical modifications," J. Adhes. Sci. Technol. 23(9), 1271-1279.

Deng, J., Wang, G., Kuang, J., Zhang, Y., and Luo, Y. (2009). "Pretreatment of agricultural residues for co-gasification via torrefaction," J. Anal. Appl. Pyrolysis 86(2), 331-337.

Dunnett, A. J., and Shah, N. (2007). "Prospects for bioenergy," J. Biobased Mater. Bioenergy 1(1), 1-18.

EN 14961-1 "Solid biofuels - Fuel specifications and classes - Part 1: General requirements," European Standard, April 2010, Pilsen.

EN 14961-2 "Solid biofuels - Fuel specifications and classes - Part 2: Wood pellets for non-industrial use," European Standard, September 2011, Pilsen.

EN 14961-3 "Solid biofuels - Fuel specifications and classes - Part 3: Wood briquettes for non-industrial use," European Standard, September 2011, Pilsen.

EN 14961-6 "Solid biofuels - Fuel specifications and classes - Part 6: Non-woody pellets for non-industrial use," European standard, April 2012, Pilsen.

EN 15210-1 "Solid biofuels - Determination of mechanical durability of pellets and briquettes - Part 1: Pellets," European standard, 2009, Pilsen.

EN 15210-2 "Solid biofuels - Determination of mechanical durability of pellets and briquettes - Part 2: Briquettes," European standard, January 2011, Pilsen.

Erlich, C., Ohman, M., Bjornbom, E., and Fransson, T. H. (2005). "Thermochemical characteristics of sugar cane bagasse pellets," Fuel 84(5), 569-575.

Faborode, M. O., and Ocallaghan, J. R. (1987). "Optimizing the compression briquetting of fibrous agricultural materials," J. Agric. Eng. Res. 38(4), 245-262.

Faborode, M. O. (1989). "Moisture effects in the compaction of fibrous agricultural residues," Biological Wastes 28(1), 61-71.

Fasina, O. O. (2008). "Physical properties of peanut hull pellets," Bioresour. Technol. 99(5), 1259-1266.

Filbakk, T., Skjevrak, G., Hoibo, O., Dibdiakova, J., and Jirjis, R. (2011). "The influence of storage and drying methods for scots pine raw material on mechanical pellet properties and production parameters," Fuel Process. Technol. 92(5), 871-878.

Finell, M., Arshadi, M., Gref, R., Scherzer, T., Knolle, W., and Lestander, T. (2009). "Laboratory-scale production of biofuel pellets from electron beam treated scots pine (Pinus silvestris L.) sawdust," Radiat. Phys. Chem. 78(4), 281-287.

Ganne-Chedeville, C., Properzi, M., Leban, J., Pizzi, A., and Pichelin, F. (2008). "Wood welding: Chemical and physical changes according to the welding time," J. Adhes. Sci. Technol. 22(7), 761-773.

García-Maravera, A., Popovb, V., and Zamorano, M. (2011). "A review of European standards for pellet quality," Renewable Energy 36(12), 3537-3540. 
Gfeller, B., Zanetti, M., Properzi, M., Pizzi, A., Pichelin, F., Lehmann, M., and Delmotte, L. (2003). "Wood bonding by vibrational welding," J. Adhes. Sci. Technol. 17(11), 1573-1589.

Gil, M. V., Oulego, P., Casal, M. D., Pevida, C., Pis, J. J., and Rubiera, F. (2010). "Mechanical durability and combustion characteristics of pellets from biomass blends," Bioresour. Technol. 101(22), 8859-8867.

Gilbert, P., Ryu, C., Sharifi, V., and Swithenbank, J. (2009). "Effect of process parameters on pelletisation of herbaceous crops," Fuel 88(8), 1491-1497.

Hagstrom, K., Axelsson, S., Arvidsson, H., Bryngelsson, I., Lundholm, C., and Eriksson, K. (2008). "Exposure to wood dust, resin acids, and volatile organic compounds during production of wood pellets," J. Occup. Environ. Hyg. 5(5), 296-304.

Heffner, L. E., and Pfost, H. B. (1973). "Gelatinization during pelleting," Feedstuffs 45(23), 33.

Hiestand, E. N. (1997). "Principles, tenets and notions of tablet bonding and measurements of strength," Eur. J. Biopharm. 44(3), 229-242.

Hoeckman, S. K., Broch, A., and Robbins C. (2011). "Hydrothermal carbonization (HTC) of lignocellulosic biomass," Energy Fuels 25(4), 1802-1810.

Holm, J. K., Henriksen, U. B., Hustad, J. E., and Sorensen, L. H. (2006). "Toward an understanding of controlling parameters in softwood and hardwood pellets production," Energy Fuels 20(6), 2686-2694.

Holm, J. K., Henriksen, U. B., Wand, K., Hustad, J. E., and Posselt, D. (2007). "Experimental verification of novel pellet model using a single pelleter unit," Energy Fuels 21(4), 2446-2449.

Holm, J. K., Stelte, W., Posselt, D., Ahrenfeldt, J., and Henriksen, U. B. (2011). "Optimization of a multiparameter model for biomass pelletization to investigate temperature dependence and to facilitate fast testing of pelletization behavior," Energy Fuels 25(8), 3706-3711.

Igathinathane, C., Melin, S., Sokhansanj, S., Bi, X., Lim, C.J., Pordesimo, L. O., and Columbus, E.P. (2009). "Machine vision based particle size and size distribution determination of airborne dust particles of wood and bark pellets," Powder Technol. 196(2), 202-212.

ISO/CD 17225-1 "Solid biofuels -Fuel specifications and classes - Part 1: General requirements," ISO - International Standard, Stage 30.60 from 28. April 2012, International Organization for Standardization, Geneva.

ISO/CD 17225-2 "Solid biofuels - Fuel specifications and classes - Part 2: Graded wood pellets," ISO - International Standard, Stage 30.60 from 28. April 2012, International Organization for Standardization, Geneva.

ISO/CD 17225-3 "Solid biofuels - Fuel specifications and classes - Part 3: Graded wood briquettes," ISO - International Standard, Stage 30.60 from 28. April 2012, International Organization for Standardization, Geneva.

ISO/CD 17225-6 "Solid biofuels - Fuel specifications and classes - Part 6: Graded nonwoody pellets," ISO - International Standard, Stage 30.60 from 28. April 2012, International Organization for Standardization, Geneva.

Jensen, P. D., Temmerman, M., and Westborg, S. (2011). "Internal particle size distribution of biofuel pellets," Fuel 90(3), 980-986.

Kaliyan, N., and Morey, R. V. (2009a). "Strategies to improve durability of switchgrass briquettes," Trans. ASABE 52(6), 1943-1953. 
Kaliyan, N., and Morey, R. V. (2009b). "Densification characteristics of corn stover and switchgrass," Trans. ASABE 52(3), 907-920.

Kaliyan, N., Morey, R. V., White, M. D., and Doering, A. (2009c). "Roll press briquetting and pelleting of corn stover and switchgrass," Trans. ASABE 52(2), 543555.

Kaliyan, N., and Morey, R. V. (2009d). "Factors affecting strength and durability of densified biomass products," Biomass Bioenergy 33(3), 337-359.

Kaliyan, N., and Morey, R. V. (2010a). "Densification characteristics of corn cobs," Fuel Process. Technol. 91(5), 559-565.

Kaliyan, N., and Morey, R. V. (2010b). "Natural binders and solid bridge type binding mechanisms in briquettes and pellets made from corn stover and switchgrass," Bioresour. Technol. 101(3), 1082-1090.

Karkania, V., Fanara, E., and Zabaniotou, A. (2012). "Review of sustainable biomass pellets production - A study for agricultural residues pellets' market in Greece," Renewable and Sustainable Energy Rev. 16(3), 1426-1436.

Kelley, S. S., Rials, T. G., and Glasser, W. G. (1987). "Relaxation behavior of the amorphous components of wood," J. Mater. Sci. 22(2), 617-624.

Kiel, J., Verhoeff, F., Gerhauser, H., and Meuleman, B. (2008a). "BO2-technology for biomass upgrading into solid fuel-pilot-scale testing and market implementation," Presented at 16th European Biomass Conference \& Exhibition, Valencia, Spain, 2-6 June 2008, Energy centre of The Netherlands, Petten. (http://www.ecn.nl/docs/library/report/2008/m08036.pdf).

Kim, Y.-H., Lee, S.-M., Lee, H.-W., and Lee, J.-W. (2012). "Physical and chemical characteristics of products from the torrefaction of yellow poplar (Liriodendron tulipifera)," Bioresour. Technol. 116, 120-125.

Kleinschmidt, C. P. (2011). "Overview of international developments in torrefaction," Proceedings of the IEA Bioenergy Task 32 and Task 40 Workshop, 28. January 2011, Graz, Austria, International Energy Agency, Paris. (http://www.ieabcc.nl/workshops/ task32_2011_graz_torrefaction/Kleindschmidt_Paper.pdf)

Lam, P. S., Sokhansanj, S., Bi, X., Lim, C. J., and Melin, S. (2011). "Energy input and quality of pellets made from steam-exploded Douglas fir (Pseudotsuga menziesii)," Energy Fuels 25(4), 1521-1528.

Larsson, S. H., Thyrel, M., Geladi, P., and Lestander, T. A. (2008). "High quality biofuel pellet production from pre-compacted low density raw materials," Bioresour. Technol. 99(15), 7176-7182.

Larsson, S. H. (2010). "Kinematic wall friction properties of reed canary grass powder at high and low normal stresses," Powder Technol. 198(1), 108-113.

Leuenberger, H., and Rohera, D. (1986). "Fundamentals of powder compression. 1. The compactibility and compressibility of pharmaceutical powders," Pharm. Res. 3(1), 12-22.

Li, H., Liu, X., Legros, R., Bi, X.T., Lim, C.J., and Sokhansanj, S. (2012). "Pelletization of torrefied sawdust and properties of torrefied pellets," Applied Energy 93, 680-685.

Li, Y. D., and Liu, H. (2000). "High-pressure densification of wood residues to form an upgraded fuel," Biomass Bioenergy 19(3), 177-186.

Mani, S., Tabil, L. G., and Sokhansanj, S. (2004). "Evaluation of compaction equations applied to four biomass species," Can. Biosyst. Eng. 46, 3.55-3.61. 
Mani, S., Tabil, L. G., and Sokhansanj, S. (2006). "Effects of compressive force, particle size and moisture content on mechanical properties of biomass pellets from grasses," Biomass Bioenergy 30(7), 648-654.

Mansouri, H. R., Pizzi, A., and Leban, J. (2010). "End-grain butt joints obtained by friction welding of high density eucalyptus wood," Wood Sci. Technol. 44(3), 399406.

Melkior, T., Jacob, S., Gerbaud, G., Hediger, S., Le Pape, L., Bonnefois, L., and Bardet, M. (2012). "NMR analysis of the transformation of wood constituents by torrefaction," Fuel 92(1), 271-280.

Miles, T. R., Miles, T. R., Baxter, L. L., Bryers, R. W., Jenkins, B. M., and Oden, L. L. (1996). "Boiler deposits from firing biomass fuels," Biomass Bioenergy 10(2-3), 125138.

Mohsenin, N., and Zaske, J. (1976). "Stress relaxation and energy-requirements in compaction of unconsolidated materials," J. Agric. Eng. Res. 21(2), 193-205.

Narra, S., Tao, Y., Glaser, C., Gusovius, H., and Ay, P. (2010). "Increasing the calorific value of rye straw pellets with biogenous and fossil fuel additives," Energy Fuels 24(9), 5228-5234.

Neville, A. (2011). "Biomass co-firing: A promising new generation option," Power 155(4), 52-56.

Nielsen, N. P. K., Gardner, D., Holm, J. K., Tomani, P., and Felby, C. (2008). "The effect of lignoboost kraft lignin addition on the pelleting properties of pine sawdust," Proceedings of the World Bioenergy Conference and Exhibition on Biomass for Energy, Jönköping, Sweden, 27-29 May 2008, International Energy Agency, pp. 120124

Nielsen, N. P. K., Gardner, D. J., Poulsen, T., and Felby, C. (2009a). "Importance of temperature, moisture content, and species for the conversion process of wood residues into fuel pellets," Wood Fiber Sci. 41(4), 414-425.

Nielsen, N. P. K., Holm, J. K., and Felby, C. (2009b). "Effect of fiber orientation on compression and frictional properties of sawdust particles in fuel pellet production," Energy Fuels 23(6), 3211-3216.

Nielsen, N. P. K., Gardner, D. J., and Felby, C. (2010). "Effect of extractives and storage on the pelletizing process of sawdust," Fuel 89(1), 94-98.

Nordwaeger, M., Håkansson, K., Li, C., Nordin, A., Olofsson, I., Pommer, L., and Wiklund-Lindström, S. (2010). "Parametric study of pilot-scale biomass torrefaction," Proceedings of the 18th European Biomass Conference and Exhibition, Lyon, 3-7 May 2010, ETA Florence, Italy (http://www.tfe.umu.se/digitalAssets/61/61391_vp2.8.5_paper.pdf).

Obernberger, I., and Thek, G. (2010). The Pellet Handbook - The Production and Thermal Utilisation of Biomass Pellets, Earthscan, London.

Odogherty, M. J., and Wheeler, J. A. (1984). "Compression of straw to high-densities in closed cylindrical dies," J. Agric. Eng. Res. 29(1), 61-72.

Odogherty, M. J. (1989). "A review of the mechanical-behavior of straw when compressed to high-densities," J. Agric. Eng. Res. 44(4), 241-265.

Olsson, A. M., and Salmén, L. (1992). "Viscoelasticity of in situ lignin as affected by structure: Softwood vs. hardwood," Viscoelasticity of Biomaterials, ACS symposium series 489 Ed., American Chemical Society, Washington, pp. 133-143. 
Panoutsou, C. (2011). "Supply of solid biofuels: Potential feedstocks, cost and sustainability issues in EU27," Solid Biofuels for Energy, Springer, London.

Peksa-Blanchard, M., Dolzan, P., Grassi, A., Heinimö, J., Junginger, M., Ranta, T., and Walter, A. (2007). "IEA bioenergy task 40 - Global wood pellets markets and industry: Policy drivers, market status and raw material potential," International Energy Agency, Paris.

Pentananunt, R., Rahman, A. N. M. M., and Bhattacharya, S. C. (1990). "Upgrading of biomass by means of torrefaction," Energy 15(12), 1175-1179.

Pietsch, W. (2002). Agglomeration Processes - Phenomena, Technologies, Equipment, Wilecy-VCH, Weinheim.

Pimchuai, A., Dutta, A., and Basu, P. (2010). "Torrefaction of agriculture residue to enhance combustible properties," Energy Fuels 24(9), 4638-4645.

Pirraglia, A., Gonzalez, R., Saloni, D., Wright, J., and Denig, J. (2012). "Fuel properties and suitability of Eucalyptus benthamii and Eucalyptus macarthurii for torrefied wood and pellets," Bioresources 7(1), 217-235.

Pirraglia, A., Gonzalez, R., and Saloni, D. (2010). "Techno-economical analysis of wood pellets production for U.S. Manufacturers," Bioresources 5(4), 2374-2390.

Pizzi, A., Despres, A., Mansouri, H., Leban, J., and Rigolet, S. (2006). "Wood joints by through-dowel rotation welding: Microstructure, C-13-NMR and water resistance," $J$. Adhes. Sci. Technol. 20(5), 427-436.

Pöyry (2011). "Pellets - Becoming a global commodity? - Perspectives on the global pellet market to 2020," View point report, Pöyry, Vantaa, Finland.

Prins, M. J., Ptasinski, K. J., and Janssen, F. J. J. G. (2006a). "Torrefaction of wood - Part 1. Weight loss kinetics," J. Anal. Appl. Pyrolysis 77(1), 28-34.

Prins, M. J., Ptasinski, K. J., and Janssen, F. J. J. G. (2006b). "Torrefaction of wood - Part 2. Analysis of products," J. Anal. Appl. Pyrolysis 77(1), 35-40.

Prins, M. J., Ptasinski, K. J., and Janssen, F. J. J. G. (2006c). "More efficient biomass gasification via torrefaction," Energy 31(15), 3458-3470.

Reza, M. T., Lynam, G.J., Vasquez, V.R., and Coronella, C.J. (2012). "Pelletization of biochar from hydrothermally carbonized wood," Environ. Prog. Sustainable Energy 31(2), 225-234.

Reed, T. B., and Bryant, B. (1979). Densified Biomass: A New Form of Solid Fuel, Department of Energy, Office of Energy Technology, Solar Energy Research Institute, Washington.

Rentizelas, A. A., Tolis, A. J., and Tatsiopoulos, I. P. (2009). "Logistics issues of biomass: The storage problem and the multi-biomass supply chain," Renewable Sustainable Energy Rev. 13(4), 887-894.

Repellin, V., Govin, A., Rolland, M., and Guyonnet, R. (2010). "Energy requirement for fine grinding of torrefied wood," Biomass Bioenergy 34(7), 923-930.

Rhen, C., Gref, R., Sjostrom, M., and Wasterlund, I. (2005). "Effects of raw material moisture content, densification pressure and temperature on some properties of Norway spruce pellets," Fuel Process. Technol. 87(1), 11-16.

Robbins, W. C. (1982). "Density of wood chips," J. Forest. 80, 567.

Robbins, M. P., Evans, G., Valentinea, J., Donnison, I. S., and Allison, G .G. (2012). "New opportunities for the exploitation of energy crops by thermochemical conversion in Northern Europe and the UK," Prog. Energy Combust. Sci. 38(2), 138155. 
Rosillo-Calle, F. (2007). "Overview of bioenergy," The Biomass Assessment Handbook, Earthscan, Oxford.

Rousset, P., Lapierre, C., Pollet, B., Quirino, W., and Perre, P. (2009). "Effect of severe thermal treatment on spruce and beech wood lignins," Ann. For. Sci. 66(1), article 110.

Rumpf, H. (1962). "The strength of granules and agglomeration," Agglomeration, John Wiley, New York, pp. 379-418.

Ryu, C., Finney, K., Sharifi, V. N., and Swithenbank, J. (2008). "Pelletized fuel production from coal tailings and spent mushroom compost - Part I - identification of pelletisation parameters," Fuel Process. Technol. 89(3), 269-275.

Sanadi, A. R., and Caulfield, D. (2008). "Thermoplastic polyolefins as formaldehyde free binders in highly filled lignocellulosic panel boards: Using glycerine as a processing aid in kenaf fiber polypropylene boards, " Mater. Res. - Ibero-Am. J. Mater. 11(4), 487-492.

Salmén, L., and Olsson, A. M. (1998). "Interaction between hemicelluloses, lignin and cellulose: Structure-property relationships," J. Pulp Paper Sci. 24(3), 99-103.

Samuelsson, R., Thyrel, M., Sjostrom, M., and Lestander, T. A. (2009). "Effect of biomaterial characteristics on pelletizing properties and biofuel pellet quality," Fuel Process. Technol. 90(9), 1129-1134.

Schubert, R., Schellnhuber, H. J., Buchmann, N., Epiney, A., Grießhammer, R., Kulessa, M., Messner, D., Rahmstorf, S., and Schmid, J. (2009). Future Bioenergy and Sustainable Land Use, Earthscan, London.

Serrano, C., Monedero, E., Lapuerta, M., and Portero, H. (2011). "Effect of moisture content, particle size and pine addition on quality parameters of barley straw pellets," Fuel Process. Technol. 92(3), 699-706.

Shah, A., Darr, M. J., Anex, R. P., and Khanal, S.(2012). "Techno-economic analysis of a production-scale torrefaction system for cellulosic biomass upgrading," Biofuels, Bioprod. Biorefin. 6(1), 45-57.

Shang, L., Ahrenfeldt, J., Holm, J. K., Sanadi, A. R., Barsberg, S., Thomsen, T., Stelte, W., and Henriksen, U. B. (2012), "Changes of chemical and mechanical behavior of torrefied wheat straw," Biomass Bioenergy 40, 63-70.

Sikkema, R., Steiner, M., Junginger, M., Hiegl, W., Hansen, M. T., and Faaij, A. (2011), "The European wood pellet markets: Current status and prospects for 2020," Biofuels Bioprod. Bioref. 5(3), 250-278.

Skøt, T. (2011). Straw to Energy - Status, Technologies and Innovation in Denmark 2011, Agro Business Park A/S, Tjele.

Smith, I. E., Probert, S. D., Stokes, R. E., and Hansford, R. J. (1977). "Briquetting of wheat straw," J. Agric. Eng. Res. 22(2), 105-111.

Smith, W. H. (1880). US Patent, 233887 A.

Sokhansanj, S., and Turhollow, A. F. (2004). "Biomass densification - cubing operations and costs for corn stover," Appl. Eng. Agric. 20(4), 495-499.

Spelter, H., and Toth, D. (2009). "North America's wood pellet sector," United States Department of Agriculture - Forest Service - Forest Products Laboratory, Madison. (http://www.fpl.fs.fed.us/documnts/fplrp/fpl_rp656.pdf).

Stelte, W., Clemons, C., Holm, J. K., Sanadi, R. A., Shang, L., Ahrenfeldt, J., and Henriksen, U. B. (2011a). "Pelletizing properties of torrefied spruce," Biomass Bioenergy 35(11), 4690-4698. 
Stelte, W., Holm, J. K., Sanadi, A. R., Ahrenfeldt, J., and Henriksen, U. B. (2011b). "Fuel pellets from biomass: The importance of the pelletizing pressure and its dependency on the processing conditions," Fuel 90(11), 3285-3290.

Stelte, W., Clemons, C., Holm, J. K., Ahrenfeldt, J., Henriksen, U. B., and Sanadi, A. R. (2011c). "Thermal transitions of the amorphous polymers in wheat straw," Ind. Crop. Prod. 34(1), 1053-1056.

Stelte, W., Holm, J. K., Sanadi, A. R., Barsberg, S., Ahrenfeldt, J., and Henriksen, U. B. (2011d). "A study of bonding and failure mechanisms in fuel pellets from different biomass resources," Biomass Bioenergy 35(2), 910-918.

Stelte, W. (2011e). Fuel Pellets from Biomass, PhD thesis, Technical University of Denmark, Roskilde, Denmark.

Stelte, W., Clemons, C., Holm, J. K., Sanadi, R. A., Shang, L., Ahrenfeldt, J., and Henriksen,U. B. (2012a). "Fuel pellets from wheat straw: The effect of lignin glass transition and surface waxes on pelletizing properties," Bioenerg. Res., 5(2), 450-458.

Stelte, W., Nielsen, N. P. K., and Sanadi, A. R. (2012b). "Pelletizing properties of torrefied wheat straw," Proceedings of the World Sustainable Energy Days, European Pellets Conference, 29 February - 2 March 2012, Wels. Energiesparverband Oberösterreich, Linz, Austria.

Stevens, J., and Gardner, D. J. (2010). "Enhancing the fuel value of wood pellets with the addition of lignin," Wood Fiber Sci. 42(4), 439-443.

Steward, A. (1950). "Pelleting of granular materials," Engineering 169(175-176), 203204.

Tabil, L. G. (1996). Binding and Pelleting Characteristics of Alfalfa, $\mathrm{PhD}$ thesis, University of Saskatchewan, Saskatoon, Canada.

Theerarattananoon, K., Xu, F., Wilson, J., Ballard, R., McKinney, L., Staggenborg, S., Vadlani, P., Pei, Z. J., and Wang, D. (2011). "Physical properties of pellets made from sorghum stalk, corn stover, wheat straw, and big bluestem," Ind. Crop. Prod. 33(2), 325-332.

Thomas, M., van Zuilichem, D. J., and van der Poel, A. F. B. (1997). "Physical quality of pelleted animal feed. 2. Contribution of processes and its conditions," Anim. Feed Sci. Technol. 64(2-4), 173-192.

Thomas, M., van Vliet, T., and van der Poel, A. F. B. (1998). "Physical quality of pelleted animal feed. 3. Contribution of feedstuff components," Anim. Feed Sci. Technol. 70(1-2), 59-78.

Tolon-Becerra, A., Lastra-Bravo, X., and Bienvenido-Barcena, F. (2011). "Proposal for territorial distribution of the EU 2020 political renewable energy goal," Renewable Energy 36(8), 2067-2077.

Tumuluru, J. S., Wright, C. T., Kenney, K. L., and Hess, J. R. (2010). "A technical review on biomass processing: Densification, preprocessing, modeling, and optimization," Presented at the 2010 ASABE Annual International Meeting, 29 July 1 August, 2010 Pittsburgh, Idaho National Laboratory. (http://www.inl.gov/technicalpublications/documents/4559449.pdf).

Tumuluru, J. S., Wright, C. T., Hess, J. R., and Kenney, K. L. (2011). "A review of biomass densification systems to develop uniform feedstock commodities for bioenergy application," Biofuels Bioprod. Biorefining 5(6), 683-707. 
Uslu, A., Faaij, A.P.C., and Bergman, P.C.A. (2012). "Pre-treatment technologies, and their effect on international bioenergy supply chain logistics. Techno-economic evaluation of torrefaction, fast pyrolysis and pelletisation," Energy 33(8), 1206-1223. van der Stelt, M. J. C., Gerhauser, H., Kiel, J. H. A., and Ptasinski, K. J. (2011). "Biomass upgrading by torrefaction for the production of biofuels: A review," Biomass Bioenergy 35(9), 3748-3762.

Yan, W., Acharjee, T. C., Coronella, C. J., and Vasquez, V. R. (2009). "Thermal pretreatment of lignocellulosic biomass," Environ. Prog. Sustainable Energy, 28(3), 435-440.

Article submitted: June 6, 2012; Peer review completed: July 12, 2012; Revised version received: July 23, 2012; Accepted: July 24, 2012; Published: July 30, 2012. 